\title{
The denaturalization of miguel de cervantes saavedra's EI igenioso hidalgo don quijote de la mancha in children's entertainment in the United States
}

\author{
Danielle Vincenza South
}

Follow this and additional works at: https://researchrepository.wvu.edu/etd

\section{Recommended Citation}

South, Danielle Vincenza, "The denaturalization of miguel de cervantes saavedra's El igenioso hidalgo don quijote de la mancha in children's entertainment in the United States" (2014). Graduate Theses, Dissertations, and Problem Reports. 7348.

https://researchrepository.wvu.edu/etd/7348

This Thesis is protected by copyright and/or related rights. It has been brought to you by the The Research Repository @ WVU with permission from the rights-holder(s). You are free to use this Thesis in any way that is permitted by the copyright and related rights legislation that applies to your use. For other uses you must obtain permission from the rights-holder(s) directly, unless additional rights are indicated by a Creative Commons license in the record and/ or on the work itself. This Thesis has been accepted for inclusion in WVU Graduate Theses, Dissertations, and Problem Reports collection by an authorized administrator of The Research Repository @ WVU. For more information, please contact researchrepository@mail.wvu.edu. 
The Denaturalization of Miguel de Cervantes Saavedra's El igenioso hidalgo don Quijote de la Mancha in Children's Entertainment in the United States

Danielle Vincenza South

Thesis submitted to the Eberly College of Arts and Sciences at West Virginia University

in partial fulfillment of the requirements for the degree of

Master of Arts in the Department of World Languages, Literatures, and Linguistics/ Spanish

Tania de Miguel Magro, Ph.D.

Pablo Garcia Loaeza, Ph.D.

Edward Martin Chauca, Ph.D.

Department of World Languages, Literatures, and Linguistics

Morgantown, WV

2014

Keywords: United States, American, Don Quixote, Sancho, Children, Entertainment, Literature, Cartoons, American Dream, New Woman, Race, Stereotypes, Mexican, European Copyright 2014 Danielle Vincenza South 
All rights reserved

INFORMATION TO ALL USERS

The quality of this reproduction is dependent upon the quality of the copy submitted.

In the unlikely event that the author did not send a complete manuscript and there are missing pages, these will be noted. Also, if material had to be removed, a note will indicate the deletion.

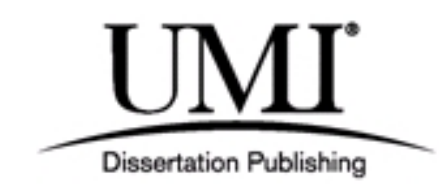

UMI 1554872

Published by ProQuest LLC (2014). Copyright in the Dissertation held by the Author.

Microform Edition () ProQuest LLC.

All rights reserved. This work is protected against unauthorized copying under Title 17, United States Code

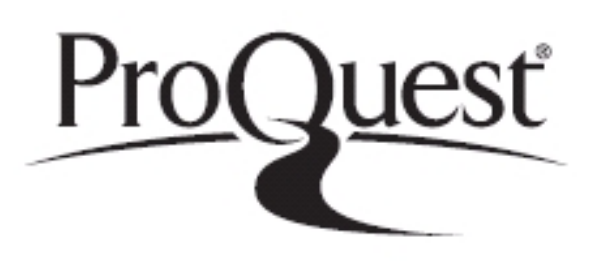

ProQuest LLC.

789 East Eisenhower Parkway

P.O. Box 1346

Ann Arbor, MI 48106 - 1346 


\begin{abstract}
The Denaturalization of Miguel de Cervantes Saavedra's El ingenioso hidalgo don Quijote de la Mancha in Children's Entertainment in the United States

Danielle Vincenza South

Versions of Miguel de Cervantes Saavedra's El ingenioso hidalgo don Quijote de la Mancha for United States children have been adapted to fit the North American target market. This research aims to identify what changes have occurred and the impact the United States' cultural touch could have on the comprehension of the original text. In the analysis to follow, the four chosen works, two books and two cartoons, demonstrate American beliefs that appeal to the intended audience. One book, entitled Adventures of Don Quixote written by Argentina Palacios, conveys the concept of the American Dream to her readers. UB IWERKS's Don Quixote also portrays the same social theory, in addition to the vision of the 1930s New Woman. The remaining two works, one book written by Cervantine expert Tom Lathrop and the other Disney's well-known Mr. Magoo series, possess racial stereotypes. The former exclusively depicts Sancho Panza as a stereotypic Mexican while the latter possesses commentary on both Don Quixote and Sancho. Disney's cartoon suggests that Don Quixote is the stereotypic European dreamer while Sancho again takes on the prejudiced Mexican image. The inclusion of the United States' culture in the selected pieces has denaturalized Cervantes's novel to create an inaccurate perception of the text and its characters within.
\end{abstract}




\section{Table of Contents}

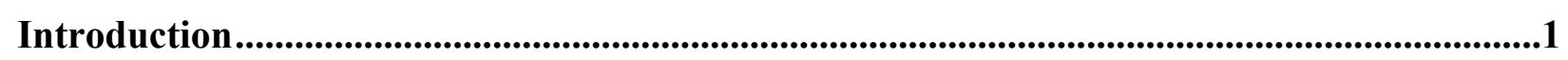

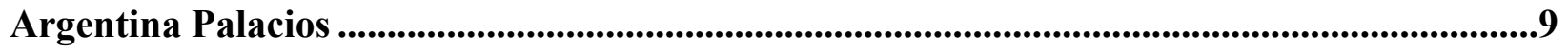

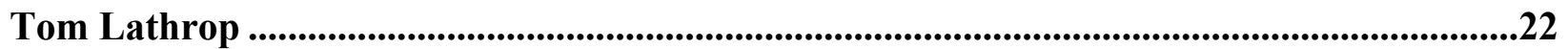

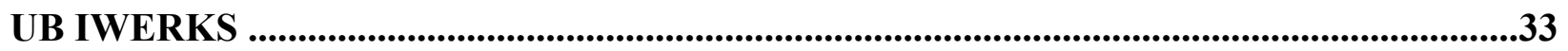

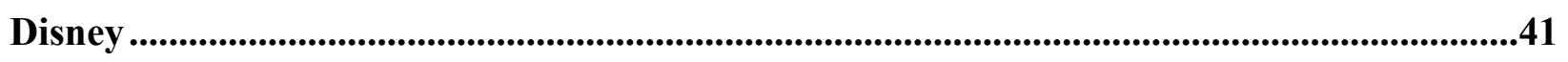

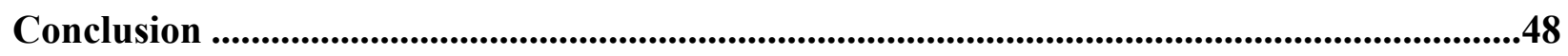

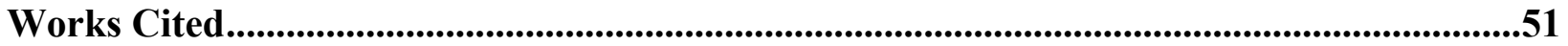


Introduction

Children's literature in the United States is written with the intent to teach a moralistic lesson. Parents, the primary market for infantile texts, prefer literary elements that impart social wisdom on their sons and daughters. When this requirement becomes essential to all youth productions, a novel written in early $17^{\text {th }}$ century Spain experiences stylistic and contextual changes that conform to these market expectations. How do the writers and the producers modify the story to reach their goal? The conversion of Cervantes's Don Quixote de la Mancha (1605, 1615) into a product for children has changed the original intent of the narration and charged the United States' Don Quixote with a kind of moral agency that he did not originally possess. There is no doubt that Don Quixote has become more than a literary figure in the United States, given the marketing goals in mind. The dilemma has come to "deciding just how sophisticated an agent he is and what exactly he is responsible for" (Tirrell).

This thesis will analyze the way that writers and filmmakers in the United States have distinctly portrayed the characters and the plotline of Don Quixote to a young North American, English-speaking audience from the early $20^{\text {th }}$ century into recent years of the $21^{\text {st }}$ and the impact that such portrayals have on society. To provide insight into how the original narration has been depicted in United States' books for children, two pieces, one written by Tom Lathrop (2012) and the other by Argentina Palacios (1999), will be analyzed. The former is an illustrated text and the latter is a chapter book with images scarcely incorporated. In addition, two cartoons will be examined: one brief animation produced by UB IWERKS (1934) with no dialogue and the other, a split, two-episode narrative $(1964,1965)$ with communication among all characters to comprise a total of 40 minutes from Disney's Mr. Magoo series. Each of the four works was 
intentionally chosen. Their difference in production and publication eras of approximately 30 years captures the unique historical frame of the time period.

There are a growing number of analyses about the cultural and sociological impact of children's entertainment in the United States. It has been proven that there are direct correlations between adaptations of canonic works and children's entertainment, indicating that the publication and production of Cervantes's Don Quixote for children is not a new development. Elements of Shakespeare's Hamlet have been identified in Disney's The Lion King; plot points of Shakespeare's Romeo and Juliet are noted in Disney's The Lady and the Tramp, as well as Shakespeare's The Tempest in Disney's Pocahontas (Johnston). The same elements present in each Disney adaptation of Shakespeare's works are present in Cervantes's novel: adventures (Scherkner), good versus evil (Fuller), love (Dewdney) and animals (Burke, Copenhaver). While each characteristic was originally included because of its correlation to knighthood tales, they are pertinent to United States children's entertainment. Animals, for example, are incorporated when the "story message is powerful or painful" (ibid.). The included moralistic lessons in the four analyzed adaptations of Don Quixote are "appropriate" for a young United States audience, meaning that taboo topics like racism (Mallory) are never stated outright.

To expand literature and cartoons to a youthful audience, the media erases cultural differences and generalizes the Latino/a community (Bender). In doing so, the complexity of ethnic and traditional distinction is avoided and an overarching understanding is achieved. However, this "comprehension" often leads to prejudiced oversimplifications of the "Latino/a" population. For example, in 2002, the animated series The Simpsons portrayed Brazilians in Rio de Janeiro as having Spanish accents, wearing mustaches and dancing the conga (ibid.). The scrutiny of the portrayal of stereotypic Hispanic characters in the media has been demonstrated 
in the analysis of the cartoon character Pecos Bill, who was originally intended for an older audience, but was later modified to appeal to children (García Loaeza 228). The survey of the Pecos Bill cartoons identifies that like the American Don Quixote and Sancho Panza, Pecos Bill is charged with cultural agency and demonstrates "the prejudice that lurks behind the apparently harmless humor" (ibid. 242).

Miguel de Cervantes Saavedra did not intend for his novel to be converted into a children's narrative. However, over time, the book has been transformed into a juvenile story containing valuable messages for young, American audiences. According to Hans Robert Jauss, the cultural background of a reader impacts the way a text will be received: "literary history is not the relationship of literary facts, but the chain of the reception of different readers in time" (Jauss 41). The intention that Cervantes had for his novel in the early $17^{\text {th }}$ century is no longer pertinent to a $20^{\text {th }}$ and $21^{\text {st }}$ century reader; the contemporary reader's interpretation of the narrative becomes the goal of the story.

No research in direct correlation between children's entertainment and the original Don Quixote has been completed. For this reason, United States adaptations of the Cervantine text needed to be further investigated to understand their implications because they are not free of collective societal influence. The intention of this thesis is to explore how knowledge of Cervantes's text in the United States is being depicted in books and cartoons for children and

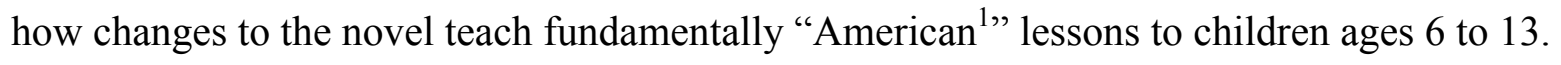

Prior to beginning my research, I conducted a survey to understand what 25 adults age range 26-75 know about Don Quixote. The goal was to have insight into how individuals who never read Don Quixote in an analytic perceive the original novel and it's intent. The participants

\footnotetext{
1 "American" in this context stands to represent the United States' citizens and culture.
} 
were primarily teachers, retired teachers and individuals in the educational field, all with high levels of education. A study group comprised of professionals in academia seemed essential because they are the individuals responsible for teaching information and cultural knowledge to the upcoming generation; these adults instill socially acceptable behaviors into today's generation. The results section below provides the most noteworthy responses during the survey, as well as analysis regarding the rest of the reactions to the questions. The survey asked if they could name any Spain-based fictional characters; if Don Quixote was mentioned, in what form, if any, they have had exposure to the story, what they know about Don Quixote as a character, what the story is about, if he/she believed there was a moral to it and if they could provide a summary of it.

\section{Survey Results}

Of the adults that mentioned Don Quixote, the knowledge of the character and storyline varied significantly. A well-educated teacher (MSA) in Montgomery County, Maryland, cited Don Quixote and Don Juan in addition to naming four other examples of characters that were created in the United States. Despite never having read Don Quixote, he identified controversial perspectives on the narration. He even recalled a debate over whether or not Don Quixote is "stupid" and added that perhaps there is still a moralistic message in the story that involves naïveté as a positive attribute.

A retired dentist and teacher who never read the story said that "[Don Quixote] set out on a journey to do good and to help correct some of the injustices that were occurring at that time (several hundred years ago). [Don Quixote] felt he was accomplishing his self-imposed task, but in reality he did little, if anything to change the times. The expression we use today to describe his impossible task is "tilting at windmills." The common use of the expression, "tilting at 
windmills," must be called to attention because when it is used in the daily vernacular, the United States perception of Don Quixote as a lunatic is perpetuated without substantial background knowledge of the novel. Wikipedia indicates that the expression means "attacking imaginary enemies" or describes "confrontations where adversaries are incorrectly perceived" (“Tilting"). Taken out of context, Don Quixote's jousts with the windmills would seem delusional distortions of reality. In the original narration, Don Quixote is an all-powerful creator, one that establishes his own world, including his own battles and enemies to defeat. Cervantes even suggests that Don Quixote was never really out-of-touch with his sanity. The way that the expression is used would never indicate this fact. While someone may know how to use the expression, there is a disconnect between how it is used in everyday conversation and the origin from which it derives. The incorrect knowledge is circulated through the idiom and exaggerations would persist.

This same teacher was also acquainted with the name Sancho Panza, and recognized him as Don Quixote's aide and “sidekick" during his adventures. This interviewee stated that there was a moral to the narration. He summarized it as "one should try to do the right thing even if it has very little chance of being successful. At the minimum, you will feel better about yourself, just as the play stated - 'dream the impossible dream."”

His wife, a retired third-grade teacher, read the story in French in her freshman year of college. She claimed that she was not able to recollect a lot of information about the narration, but she surprisingly remembered intimate details of the narration. She stated:

The story follows the adventures of Don Quixote who read novels about chivalry and decides to set out to revive chivalry. He brings along Sancho Panza, a farmer, as his squire. They travel thru Spain in search of glory and adventure. Along the 
way he falls in love with Dulcinea, who he thinks is a princess. A priest and a barber drag him home, thinking he is crazy and try to cure him.

Additionally, she recalled Cervantes as the author of the novel, and even recollected, "Don Quixote attempted to defend the helpless and destroy the wicked." She also stated that he did not do much good in righting the wrongs of the world, but spent time "tilting windmills."

Perhaps the most in-depth analysis, despite not reading the story, was provided by a 50 year-old college professor in Montgomery County, Maryland. She recalled Don Juan, Don Quixote, The 3 Caballeros, and Zorro. She gained knowledge of the Don Quixote from the play "Man of La Mancha." She was the only interviewee that commented on the exaggerated depiction of each of the fictional creations. She described Don Quixote as a crazy person riding away on a donkey, "tilting at windmills." When asked about the moralistic fibers of the works she listed, she stated,

Don Quixote looked at the world and saw things as he wanted to and not always as they really are. He saw people where there were windmills and saw possibilities where there was only the impossible. The lesson there is that we cannot control life but we can control our reaction to life events.

Her husband, another college professor, was the most honest interviewee. He stated that his only knowledge of Don Quixote stems from "Man of La Mancha" and that perhaps by seeing this play, his understanding of the story was hindered. He did provide information regarding Don Quixote's representation as a dreamer who wanted to be an adventurer and revive chivalry, Sancho Panza who was his squire, Don Quixote attacking windmills that he thinks are beasts or giants, and that he falls in love and becomes devoted to a woman named Dulcinea. He confessed that he found the theatrical performance hard to follow and difficult to relate to, but did propose 
the theory that in Spanish, it would have a stronger message and be more relatable. Despite discomfort with the story and a lack of explicitly-stated exposure, he presumed that the moralistic message would be to follow one's dreams and to strive to do something worthwhile.

The head of the Office of Accessibility Services at West Virginia University was an English major with a minor in Philosophy. He received his Ph.D. in education and was a teacher before transitioning into his current position at the university. Not only did he understand the process of analyzing literature, but understood more than any other interviewee about what longlasting message can be taken away from a piece of writing. When asked if he believed there was a moralistic message in Don Quixote, he replied that none of the classic philosophers' perspectives fit into the story, although he did admit that he had not read the book for some time. While in college, he read and analyzed the novel but confessed that he completely missed the point of the story. According to his own self-analysis, the lack of historical background influenced his inability to understand the goal of the narration. He is an avid reader and still follows the current production of all literature. He commented after reading Tom Lathrop's version of the novel, that it is "totally off the mark." As a college student, he did not understand the message of the original narration (English version); he even questioned how a child could understand the story. He hypothesized that if in fact a child did understand the version of the text placed in front of them, their understanding of the narrative would be inaccurate.

Other interviewees that mentioned Don Quixote were aware of some general characteristics of the story. Fighting as a knight, Sancho, the donkey and the windmills were noted as facts even when the story had never been read, or if he or she had been only exposed to "Man of La Mancha" or a cartoon version of the novel, such as the UB IWERKS adaptation. 
It is surprising to see that despite the individuals' education levels there was a lack of exposure to the story in its entirety. The recurrence of the expression "tilting at windmills" and reference to "Man of La Mancha" contributes to the distorted perception of the novel. If these are the most common references to the story, it is not surprising that there is a misunderstanding of the original narration and its characters. 
Version Written by Argentina Palacios: Adventures of Don Quixote Argentina Palacios's text is comprised of 59 pages and is written in English. Palacios's Adventures of Don Quixote (1999) is intended for audiences approximately 10 to 13 years of age based on the linguistic level of the text and inclusion of melancholic events. The gloomiest moments are shown through the insertion of five pictures in the book that depict scary and depressing truths. There is an introductory note to the text and the original author prior to presenting the table of contents. The book consists of 20 chapters that narrate the life of Don Quixote. Each chapter has a maximum of four pages. Palacios transformed Cervantes's 1,106 pages into a children's book of less than 60 pages, omitting over $90 \%$ of the original text. Palacios does not conserve many elements of the original novel, and the Cervantine context she chose to eliminate changes the initially intended message. The events that Argentina Palacios has chosen to retell insinuate that the main intent of her version is to express Don Quixote's absolute dedication to the recreation of a chivalrous world, independent of the historical context during which his adventures took place. Palacios wrote a book that is easy to remember, but excludes the emotion felt by the changing $17^{\text {th }}$ century Spanish society that Cervantes captured in his novel.

If children in the United States received the message as Cervantes intended, they would feel a sense of irreparable hopelessness. The original Don Quixote is not a sellable children's story in the United States because the protagonist desperately attempts and fails to reinstate a way of life that is dead. When he cannot achieve his purpose, he dies for he would rather be nonexistent than survive in a world where his core values no longer have meaning. In a sense, Don Quixote is the opposite of the American Dream. If Palacios included the Cervantine goal of the novel, her book would not sell because Don Quixote could illicit anxiety amongst young, 
American readers. Since adults are the target market for children's literature, she must appeal to their desires to provide delightful, uplifting literature for their children. American parents prefer that their impressionable children read books that include principles of triumph and victory, elements that compose the concept of the American Dream rather than difficult truths of life. In order for a story to achieve financial success amongst a United States' youth population, the story must be understood without causing fear of failure in the world. An American parent wants to teach their young child that if one works hard enough in spite of obstacles, one will achieve his or her goals and that is exactly the message that Palacios employs.

Palacios is able to depict elements of American patriotism and support American ideals in Adventures of Don Quixote when she takes her version of the story out of the context of $17^{\text {th }}$ century Spain. Even with the remarks at the beginning of her narration that place the action of the story in the heart of Spain, the child reading the story still has no cultural frame of reference; the child would not understand life in this setting. Therefore, the connections that are being made to the backdrop of the story are based on the experience of a young United States audience. First, Don Quixote's self-proclaimed name "Don Quixote de La Mancha” could be perceived as a demonstration of pride for his origin. This supposed honor comes from developmental teachings to which the child is exposed that one should always feel privileged to be an American. With the appropriate foundational understanding of knightly novels, however, one would be able to comprehend that his title is actually a paradoxical example of a chivalric name. The rural characteristics of La Mancha are undesirable, after which one would not typically name oneself. The use of "Don" is explained at the beginning of the text as an expression of his family's social stature. Don Quixote as an individual, however, is not financially above others: "He inherited a little land, but very little else" (Palacios 2). "Don" would have historically been used as an 
honorific term for members of nobility. When applied this way as Cervantes intended, "Don" places Don Quixote in a more prominent class. In Adventures of Don Quixote, this fact is ignored and the concept that all men are created equally is implemented. American children are taught in school that in their nation, no one is better or worse than anyone else. When Don Quixote is giving Sancho governing advice, he instructs Sancho to remain humble: "Don't ever discuss family backgrounds, or compare one with another. No one is better than anyone else. You only stand to make enemies when you make comparisons" (Palacios 43). To a child from the United States reading this book, this piece of advice is interpreted as support for the belief of equality for all, even though Cervantes originally intended Don Quixote's guidance to reflect on his sanity.

Sancho Panza is a relatable, idealistic American character as a "practical-minded" (Palacios iii) work-hand. He exemplifies the goal of the American Dream: coming from the working class to an opportunity to achieve greatness. When he is offered the chance to leave his home and travel with Don Quixote, he is overjoyed at the ability to change professions: "I'd be rich! I'll never have anything if I stay home and work nonstop for the rest of my life! I can send money to my family from the island!” (ibid. 9). Sancho takes advantage of the prospect to climb the financial ladder, even if his method to do so is unconventional. His desire to achieve his own higher social status makes him support Don Quixote's adventures. Don Quixote and Sancho both come from a small town where he and two prior generations have always lived; their families do not support their decision to leave home. Palacios indicates through the actions of both characters that it is never too late to be the first in the family to push the boundaries and explore the rest of the world. In the United States, the concept of the "self-made man," or someone who despite all odds overcomes obstacles and triumphs, is therefore embodied in Don Quixote and 
Sancho. They set out to prove their bravery despite the pushback from family, friends and the strangers he encounters. When Don Quixote decides to battle the lions, he does not accept complacency from either the lion keepers or the lions themselves. He provokes the men to open the cage, when one of them responds that Don Quixote must be crazy. Sancho hears the insult and defends his master, "No, he's not crazy, just bold" (Palacios 28). Despite the attempts of others to dissuade Don Quixote from facing the lions, Sancho supports him. His support gives Don Quixote the courage to dominate the lions and prove his valor. In the United States, many dreams have been scoffed at when they were seemingly too big to accomplish, but it only takes one supporter to believe in the ultimate goal that gives hope for completion. For Don Quixote, his dream is to one day be known as the bravest and most famous knight. Because Sancho believes in him, he is encouraged to continue in his quest. Don Quixote's actions embody American optimism, the notion that despite all odds, one can still triumph. There are certain occurrences in which such hope is not present, such as Don Quixote's first defeat by the windmills, Sancho and Don Quixote's imaginary ride on a wooden horse, Don Quixote's pathetic defeat of the lions, Sancho's short-term reign of his island, Don Quixote's encounter with "Dulcinea," and finally, Don Quixote's death. Each of these events is disheartening because each one represents a failure. The 1999 edition of Palacios's Adventures of Don Quixote (1979) incorporates images of the five events that suggest a glimmer of optimism. While the images were not originally included, this later interpretation perceived the necessity of softening the blow of each melancholic moment through the inclusion of a light-hearted illustration. 


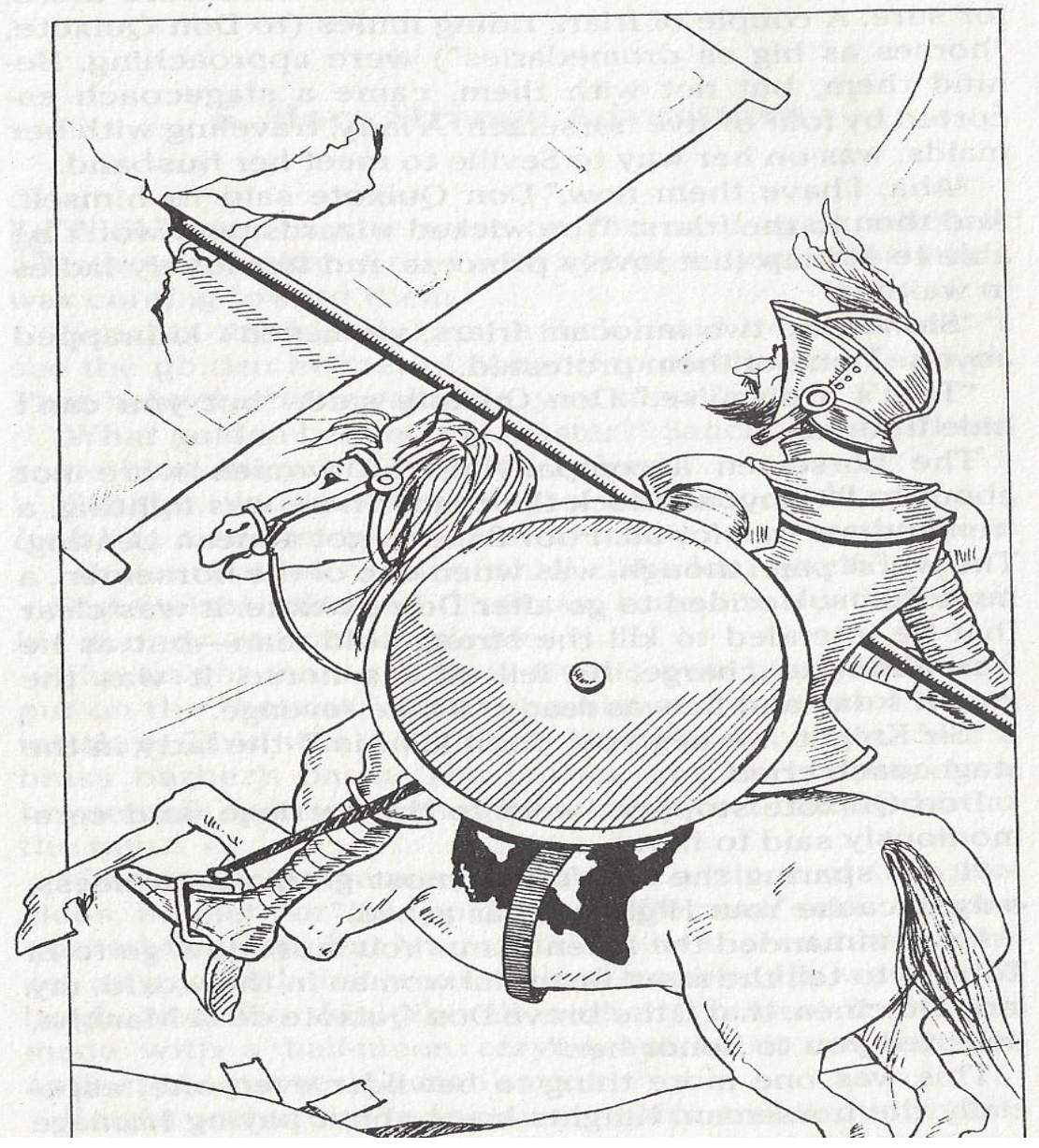

Don Quixote's first adventure is the attack on a windmill that he perceives to be a monster. He is thrown from his horse and injured. The caption, "At Rocinante's fastest gallop, he charged and lanced a sail" implies victory. 


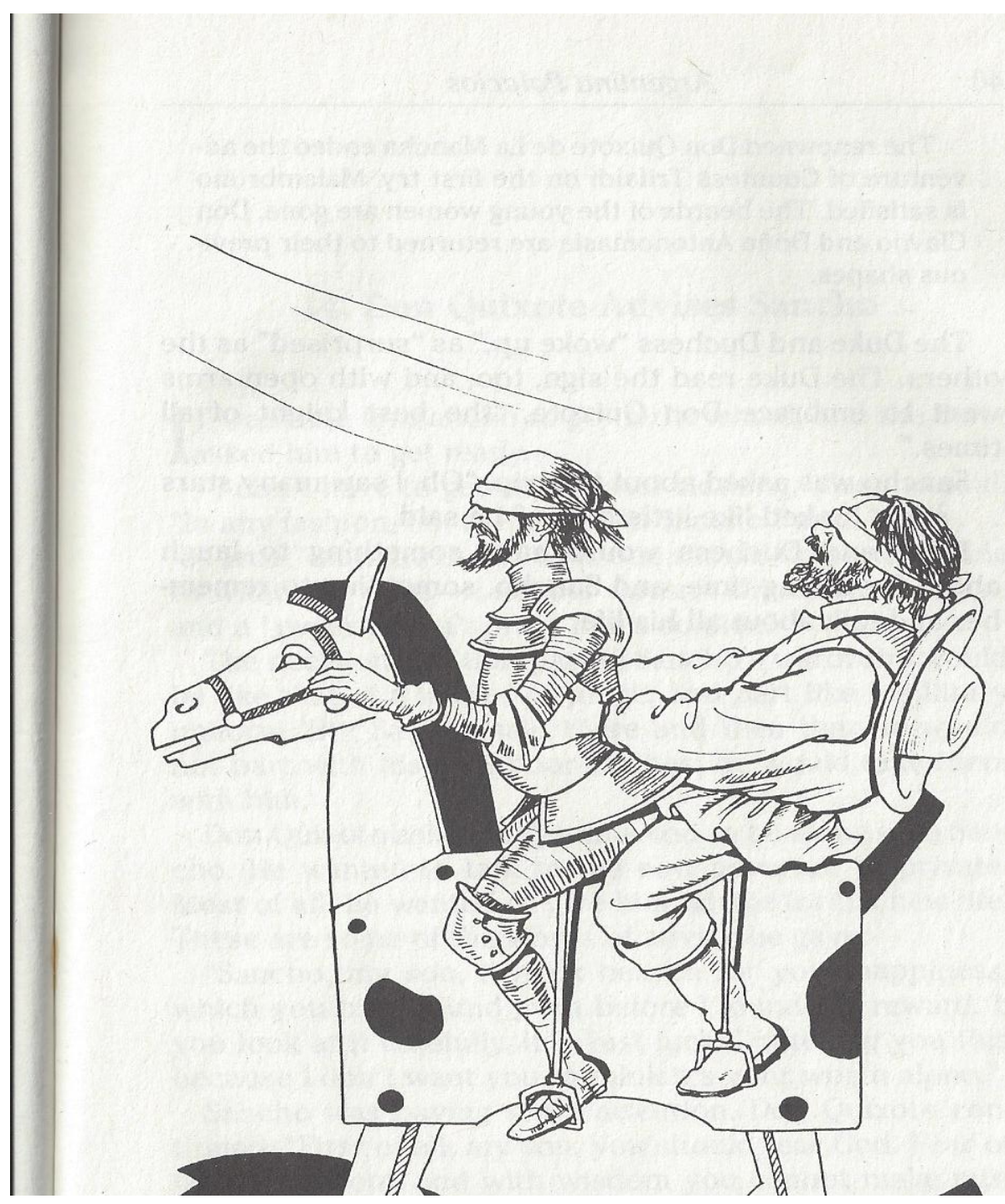

Don Quixote and Sancho are made to look like fools when they imagine their mystical flight on Clavileño, a horse made out of wood and pegs. The image takes the sting out of the embarrassment to make it appear as though the pair is simply playing on a toy horse. 


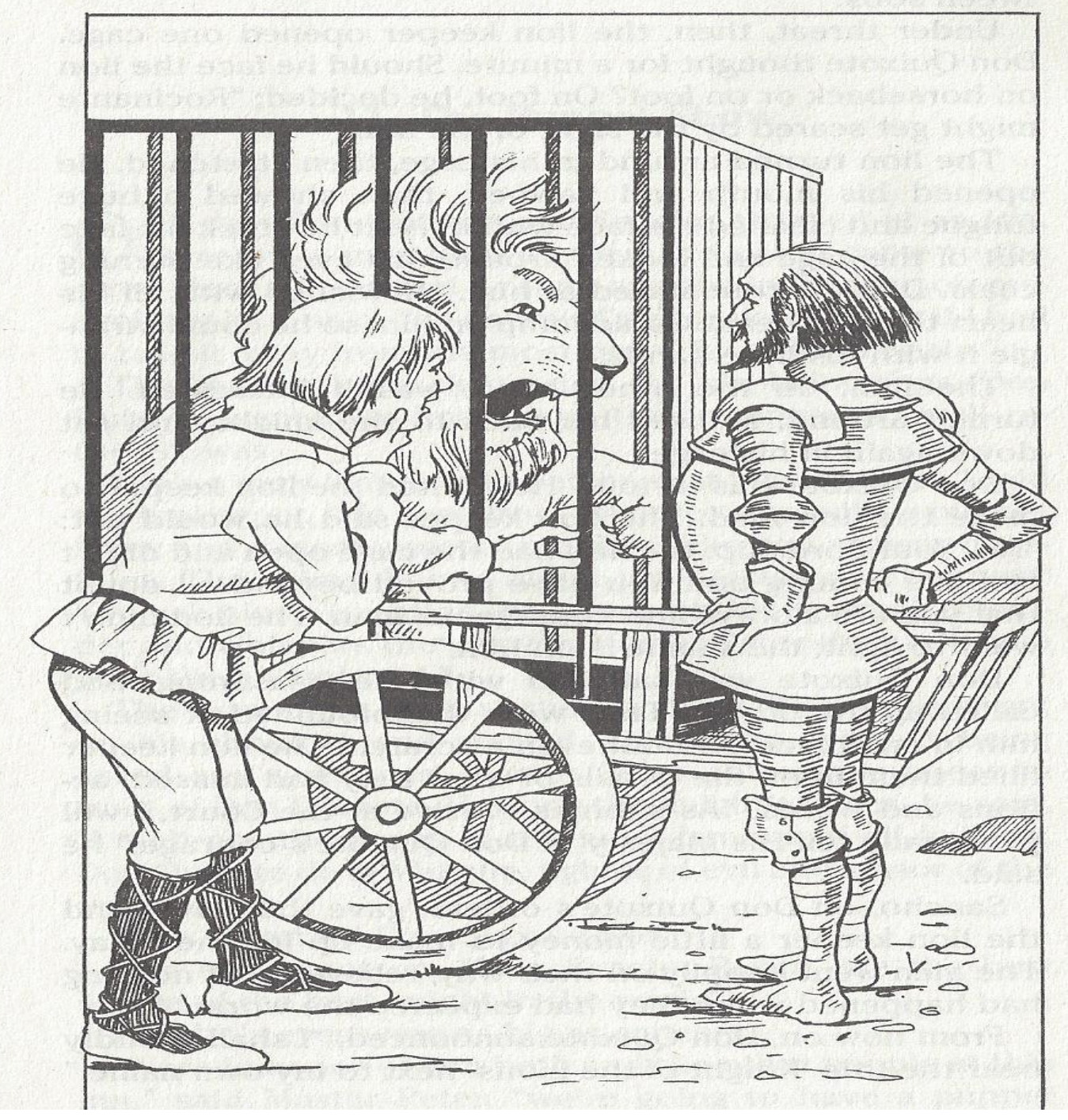

Don Quixote battles lions that do not even stand-up to attack him, even though the picture suggests that the beasts were rather ferocious. With the animals portrayed as fierce, Don Quixote is seen as a true victor, triumphing over a fight that would have typically been lost; he is a hero. Palacios's narrative suggests otherwise. 


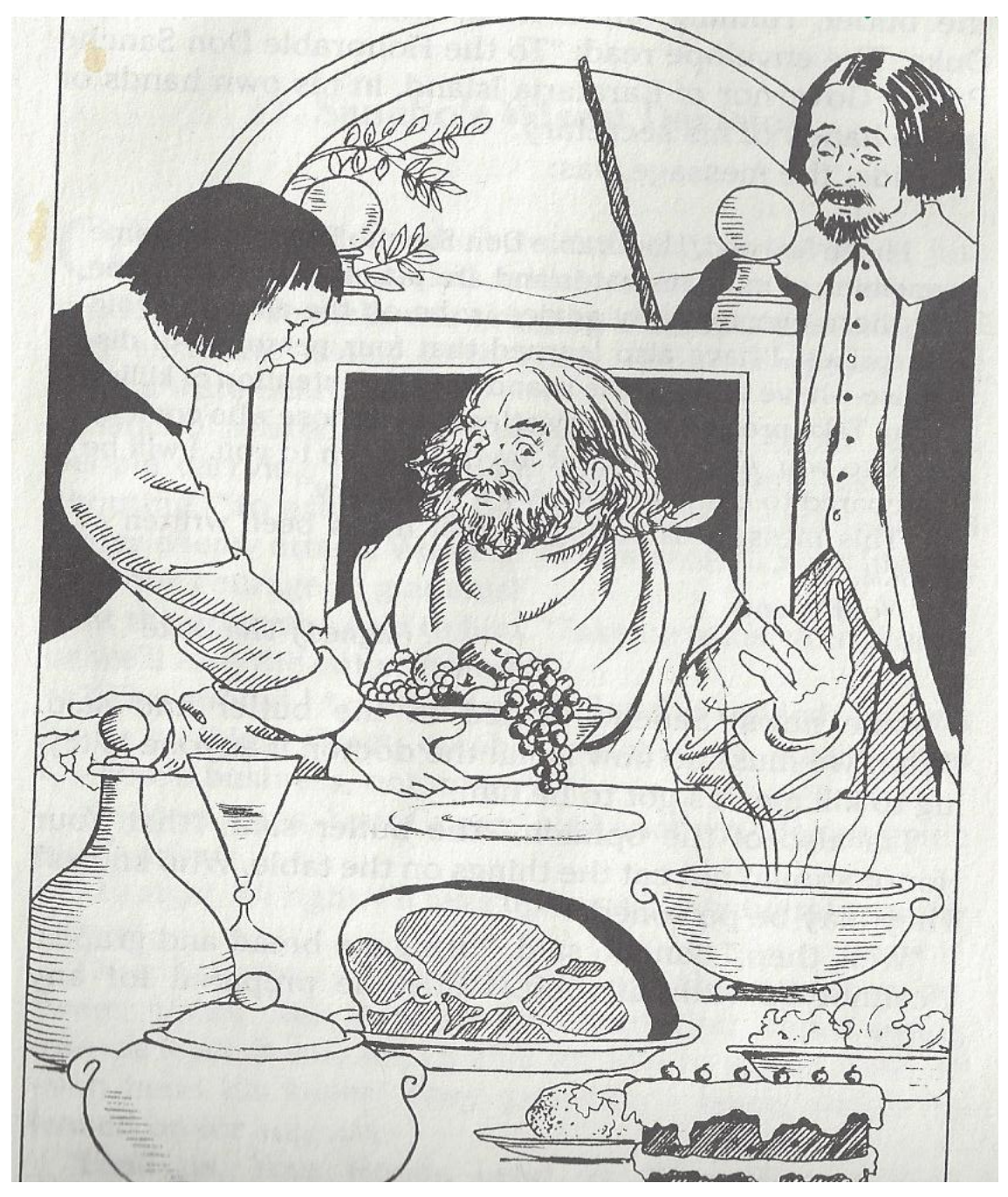

When Sancho is governor of his island, he is overwhelmed by the threat of being poisoned. His chance to be successful is ruined when his fears consume him and he does not remain governor for long. The image shows Sancho suspicious of a delicious banquet, and portrays the smiles of the other men present, as if to say that this event was mainly joyful. 


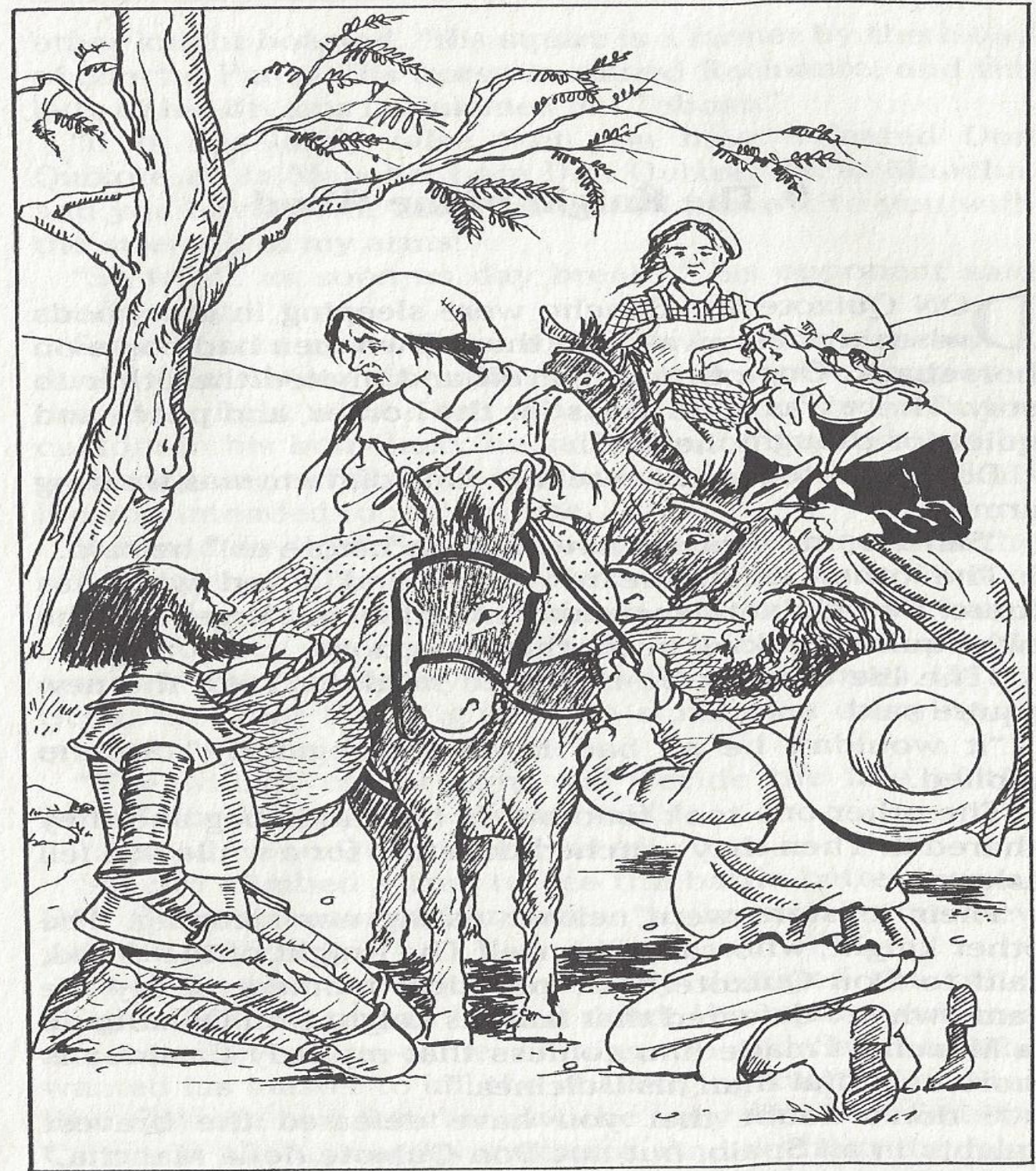

Don Quixote's attempt to woo "Dulcinea," actually a random farm girl, is futile. She does not humor Don Quixote in the slightest, telling him to get up and move on so she can proceed. The image infers "Dulcinea's" confusion, but does not express the same disgust as Palacios states in her text. 


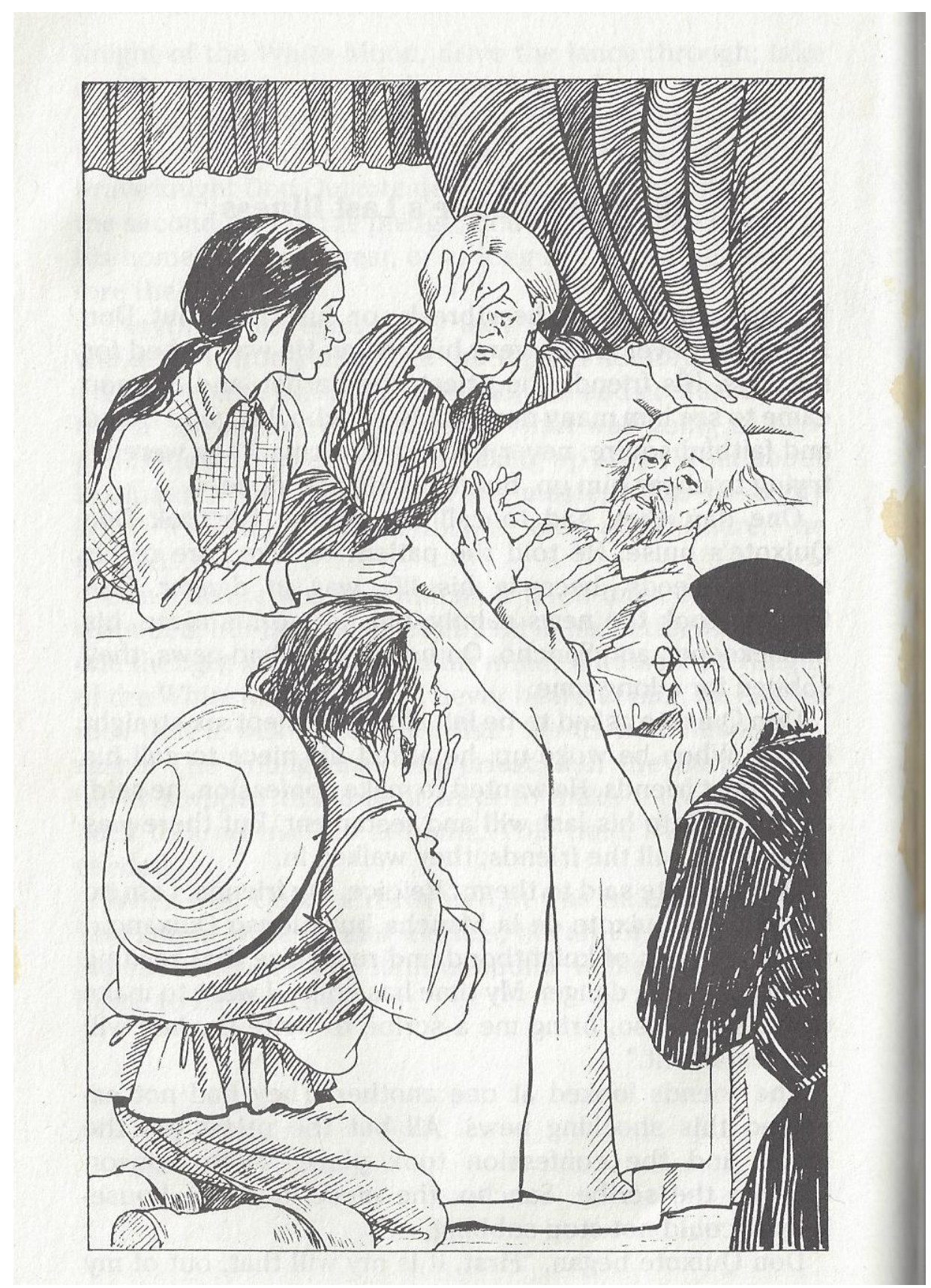

Death is a characteristically melancholy event. However, the eye contact that he makes with each of his loved-ones that surround him suggests that he was lucid when he passed away. At the time of his death, everything was all right in the world. 
To lessen the impact of the emotional horror of the events, each event is prefaced by explicit chapter titles that provide a "heads-up" to the young reader to avoid frightening him or her. Establishing and maintaining uncertainty throughout the narrative would violate the central theme of the American Dream, which is centered on knowing that the protagonist of any situation will ultimately emerge victorious.

1. A Knight in Armor

2. Don Quixote Leaves Home

3. The Price of Meddling

4. Don Quixote and Sancho Panza Have Some Strange Adventures

5. More Strange Adventures

6. Back to La Mancha

7. Don Quixote Learns He Is Already Famous

8. On the Road Again

9. The Knight of the Wood

10. The Adventure of the Lions

11. The Puppet Show

12. At the Duke's Palace

13. The Adventure of the Wooden Horse

14. Don Quixote Advises Sancho

15. Sancho, Governor for Life

16. Danger at the Island

17. Sancho's Wisest Decision

18. Knight and Squire Reunited 


\section{The Knight of the White Moon}

\section{Don Quixote's Last Illness}

In Palacios's text, Don Quixote experiences tribulations, yet remains optimistic. When a servant stones him, he continues on his journey believing that, "all knights in armor had a little bad luck now and then" (Palacios 8). The clarity from the titles listed below gives the reader a sense of security at the beginning of each event that despite all, confidence is never lost. This depiction of ever-glowing possibility is a reflection of the American Dream in which all humans live happily ever after. Chapter 18, "Knight and Squire Reunited” joyously paints the rejoining of Don Quixote and Sancho Panza. Despite the humiliation Don Quixote has experienced thus far in the story, and Sancho's failure as a governor and his embarrassing fall into the cave with his donkey, the focus of the reunion is placed on the fact that the two are finally back together again. When Don Quixote rescues his squire, Palacios paints the image of a valiant, heroic duo riding off into the sun after their numerous and exhausting journeys, describing their emotional state upon return to the palace as, "a happy pair" (Palacios 53).

Despite all of the failures that Don Quixote experiences in battle, he is always given another chance to emerge victorious. No matter the outcome of any confrontation, the American Dream employs the notion that there is always the potential to pick up and try again. At the end of the book when he faces the Knight of the White Moon and is defeated, Don Quixote is spared his life and allowed to live to fight another day. Although he loses the duel, he survives physically with his pride intact. Even when Don Quixote falls ill in Palacios's final chapter, his death is not in vain. Don Quixote is shown to have lived a full and accomplished life despite becoming unwell. His foolishness inspired him to behave the way he did, but he made his dreams come true. When he has finished writing his will, Palacios states that for the last three days that 
Don Quixote lived, he behaved sanely and "constantly said how much he hated those books that had made him crazy" (ibid. 59). However, Don Quixote never confesses that he regrets his actions for they were the embodiment of his desires, and "[Don Quixote] taught [Sancho] to fight for what one believes in" (Palacios 59). Don Quixote was able to chase after his goals because the American Dream dictates that no dream is too ridiculous to pursue. And despite the lack of support from his family throughout his adventures, he was accompanied by his faithful sidekick, Sancho, and was still surrounded by his loved ones when he passed away. 
Illustrated Version, The Misadventures of Don Quixote written by Cervantine expert, Tom Lathrop

While Palacios's Adventures of Don Quixote principally tells the story through textual narrative, Lathrop tells his version of the Cervantine novel through illustrations. Since the mode of communication is distinct, the delivered message differs from Palacios's. Lathrop published this juvenile version of Cervantes's text in 2012. There are 32 in-color illustrated pages by artist Jack Davis with accompanying text. The simplified narrative and the style of illustrations gear Lathrop's text toward an audience of children 6 to 8 years of age.

Lathrop's story begins by introducing Don Quixote, the old country gentleman who "dreamed of adventure and spent every spare moment reading old tales about valiant knights" (Lathrop 1). Don Quixote becomes enveloped in the stories he reads; he decides that he must become a knight. Unlike the heroes in the stories, he does not have a lady, a horse or a squire. $\mathrm{He}$ dubs those around him as such, although none of them are really the way the chivalric books dictate they should be. Don Quixote, his horse, and his squire then set out on their adventures. Don Quixote battles a windmill, sheep and shepherds, obtains Mambrino's Magic Helmet, duels with leather wineskins, and confronts lions. Sancho Panza also has his share of adventure as the governor of an island given to him by a Duke and a Duchess where he must alleviate conflict among the inhabitants, although his reign does not last long. Don Quixote's family and friends are concerned about his time away from home and ask a student to get him to return. Ultimately, the student achieves in getting Don Quixote and Sancho to stay home for one year. Everyone is ecstatic to see the pair's homecoming, and Don Quixote and Sancho are excited for the adventures to come at the end of their year home. 
Before entering the pages of the text, the title of Lathrop's book, The Misadventures of Don Quixote, is a misnomer. "Misadventure" is defined as an unfortunate event or mishap, and is synonymous with accident, problem, or misfortune ("Misadventure"). The connotation of this term incorrectly characterizes Cervantes's El ingenioso hidalgo don Quixote de La Mancha. The original Don Quixote acts deliberately. "Misadventure” alludes to foolishness or stupidity whereas in contrast, Cervantes characterizes Don Quixote as “ingenious," and within the text, implies that he may have actually been faking his lunacy. There is no doubt that a young reader would overlook the use of the term "misadventure," and be unaffected by it because he or she does not understand the meaning. Most likely, it was used because of the typical, classic, storybook titles, such as The Adventures of Huckleberry Finn or The Adventures of Tom Sawyer. Since Don Quixote is not the typical tale of a valiant knight, Lathrop used the counterpart to "adventure" to describe his version of Cervantes's text.

Inside the book are alterations between Lathrop and Cervantes's texts in regards to chronology and facts. Prior to embarking on his first adventure, Lathrop's Don Quixote contracts Sancho to be his squire. Originally stated, Don Quixote's first adventure is done alone. Upon his return, he recruits Sancho, and then they embark on their first adventure together. The second change is the end in which Don Quixote and Sancho Panza are shown heading home after Don Quixote has been defeated and has promised to stay in La Mancha for a year. The text on the final page reads, "It was a joyful reunion, made even more joyful by the promise of adventures to come at the end of their year at home!" (Lathrop 32). Not only is this depiction factually incorrect for Don Quixote returned home after being knocked unconscious and carried home like a deer, the use of the term "joyful” would make it seem as though Don Quixote returned willingly and that all were simply thrilled to have Sancho and Don Quixote home. In Cervantes's 
novel, upon Sancho's return, his wife immediately inquires about what he brought her back. She is displeased to learn that he has nothing to show for the time that he has been away. Additionally, Don Quixote's niece and housekeeper originally express their concern about his madness; they fear he will leave again. Sancho's wife's displeasure as well as the concern of Don Quixote's loved ones are not included in Lathrop's description of their “joyful” return home. This closing of Lathrop's book is one clearly intended for young children. Lathrop's ending is a "and they lived happily ever after" style of closing. The "joyful" homecoming of the pair and the positive outlook on the years to come indicates that all is well, and reasonably so. How could a children's book end with Don Quixote's sad and tragic death? The ending of Lathrop's book is one prime example of why the narration cannot be retold faithfully to a young audience. There are topics deemed "inappropriate" for the 6 to 8 year-old age group, and stating how Cervantes's novel tragically ends is one of them. This finale to Lathrop's narration indicates the inability to express the narration as it was intended - for an older audience that can handle societal and life truths told in Cervantes's Don Quixote.

A young reader will primarily focus on the incorporated drawings, and the way they complement the narrative and portray characters. If done properly, he or she can achieve a more in-depth understanding of the textual narrative. If done ineffectively, the illustrations distract from the intent of the written story. It is imperative to identify the way in which they accompany Lathrop's written narrative in The Misadventures of Don Quixote, and the effect that their implementation could have on Cervantes's original message in Lathrop's version of the text. Jack Davis's illustrations occupy the majority of the space on each of the pages. One of the main accomplishments of Davis is that he appropriately depicts the differences in Don Quixote's perceptions and reality. The way that Don Quixote envisions Rocinante, Sancho Panza, the 
windmills, the wineskins and the sheep are drawn with superimposed or juxtaposed images of his imaginary confidants and enemies. It is crucial in Cervantes's text that the reader understands the madness that Don Quixote portrays. His imagined chivalric title drives him to leave home in search of knightly adventures. He gallivants around La Mancha, perceiving the world as a classic knighthood novel. In this respect, Davis's drawings include this fundamental element. The illustration of the windmill in Lathrop's book, for example, shows the reality colored in and explicitly outlined while Don Quixote's imagination is a gray sketch superimposed over top. The battle with the herd of sheep that Don Quixote perceives as an army, and the late-night fight with the wineskins Don Quixote dreams is a monster are all similarly portrayed in color with superimposed, sketch-like images of Don Quixote's perception of reality. He concocts in his mind's eye that his confidants, Sancho and Rocinante, and his love, Dulcinea, are more valiant and beautiful than they really are. The reader is able to understand Don Quixote's delusion, demonstrated by juxtaposed images of their real appearance and Don Quixote's picturing of each of them. Regardless, there are moments of Cervantes's novel in which the reader believes that Don Quixote is not actually crazy, but in fact fully aware of his actions and is just playing makebelieve. This ambiguity is not present in Lathrop's text.

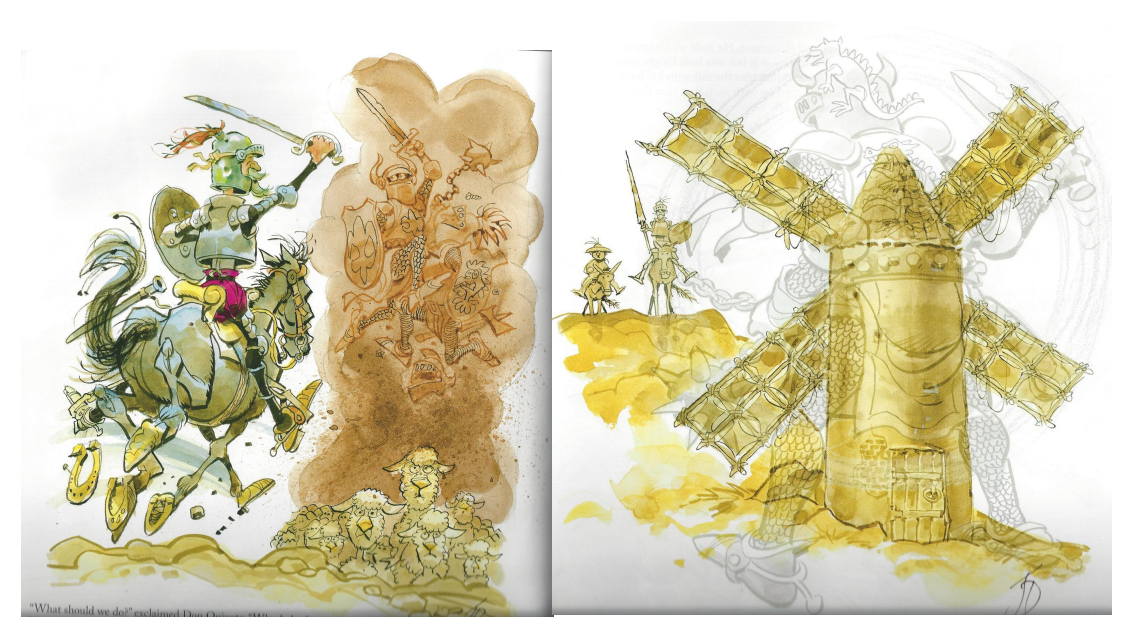



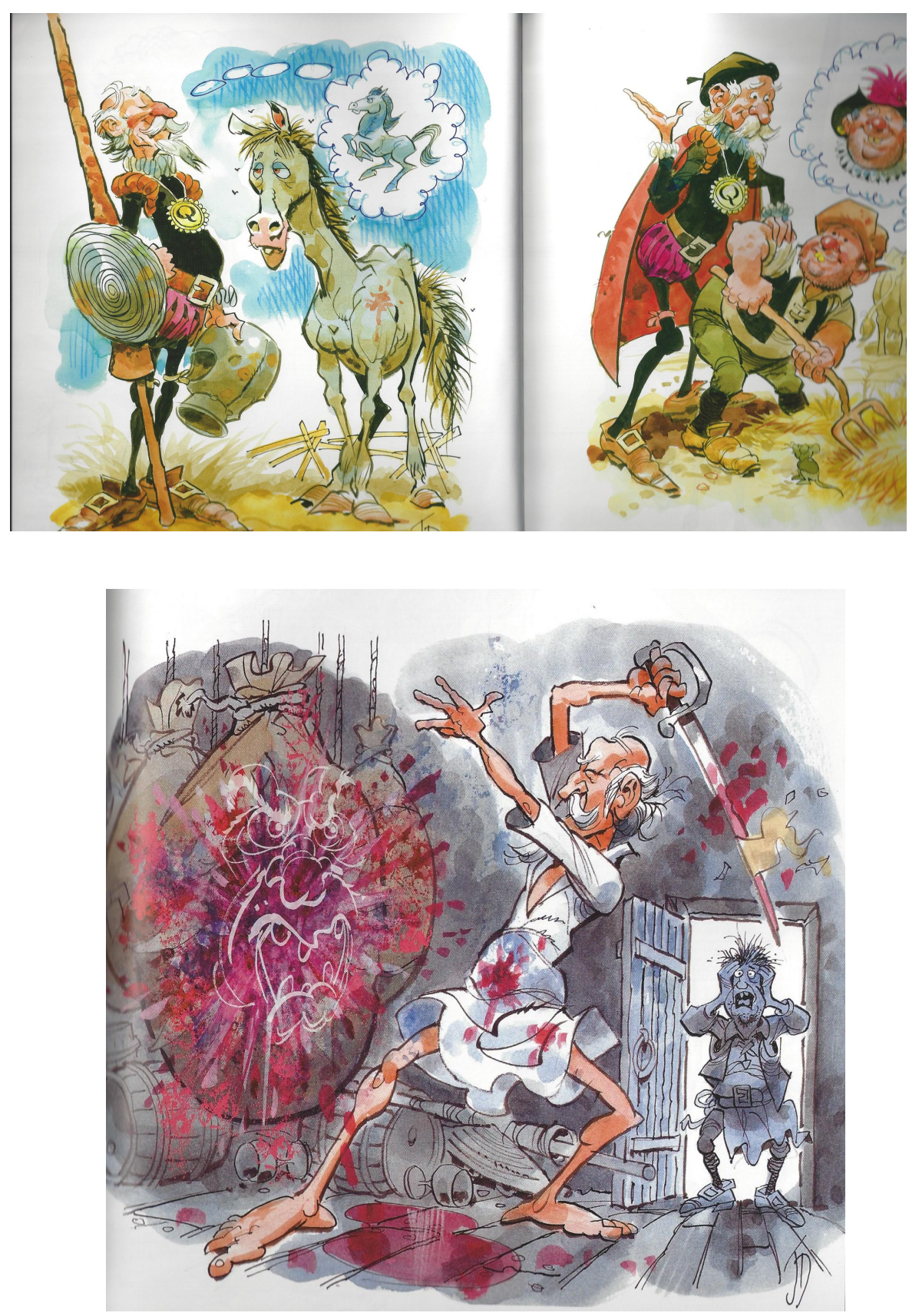

Not all of the differences in reality versus Don Quixote's perception are demonstrated with such clarity. At times, Davis's illustrations contradict the narrative text. The first image on the first page states that "the village barber and priest were his best friends" though the picture suggests otherwise. In the background, the priest is seen whispering to the barber. If pictures are meant to clarify the words in the book, this picture does not satisfy that objective. For an adult 
that understands the original novel, one could infer that Davis is trying to implement the idea that the individuals that Don Quixote perceives as his best friends are actually individuals that mock his behavior. However, for a child that is receiving the message both through text and through images, the illustration would only cause confusion.

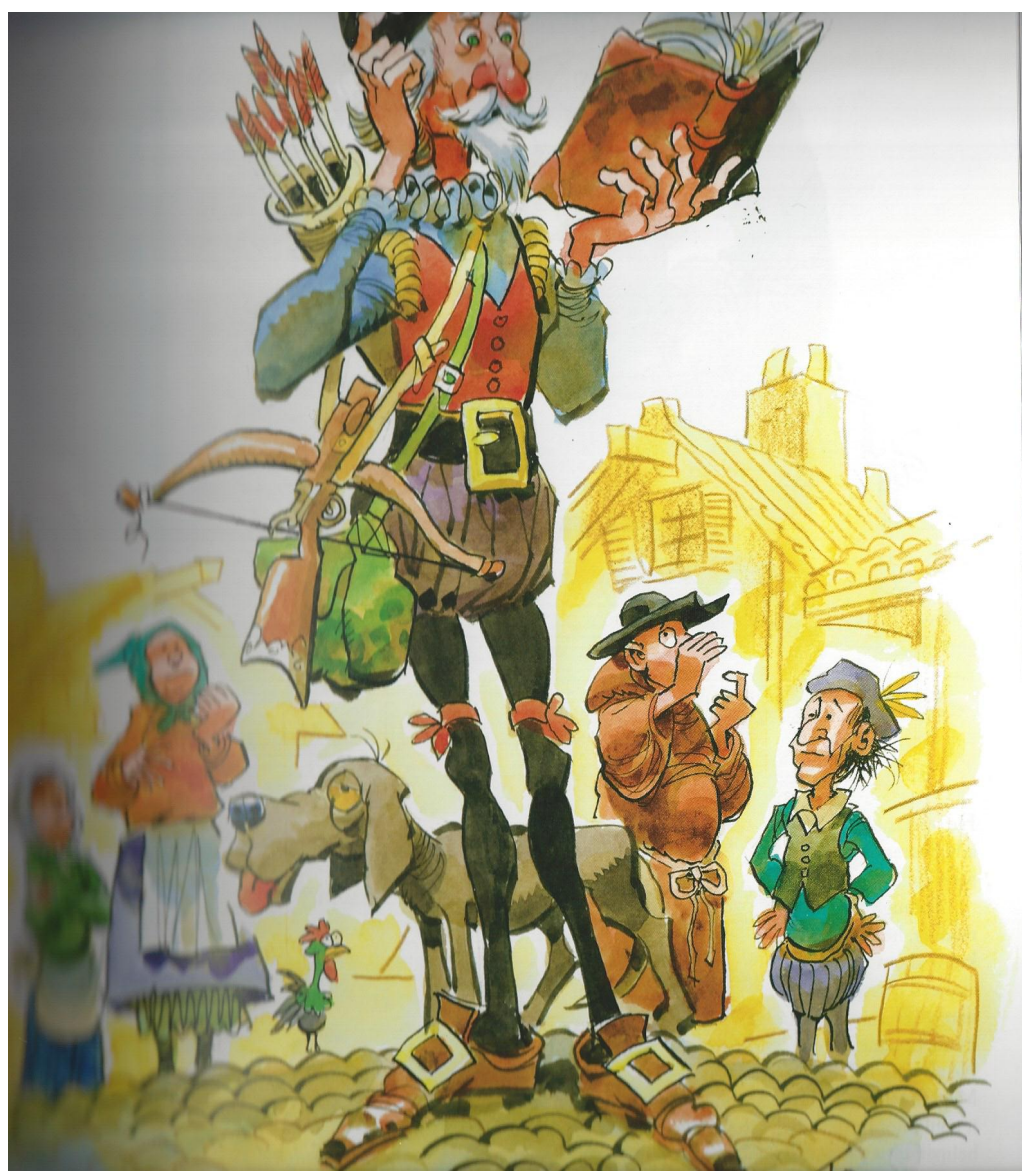

Another example of the same type of contradiction between image and text is present in the naming of Dulcinea as Don Quixote's love. The text states that "He'd never even met her," yet the image suggests to Don Quixote's direct sight of her. In the image, seeing her evokes Don Quixote's perception that she is a princess, rather than the farm girl that she actually is. While 
Don Quixote's distortion of reality is accurate, the fact that Don Quixote is drawn in the line of sight of Dulcinea is contradictory to the text.

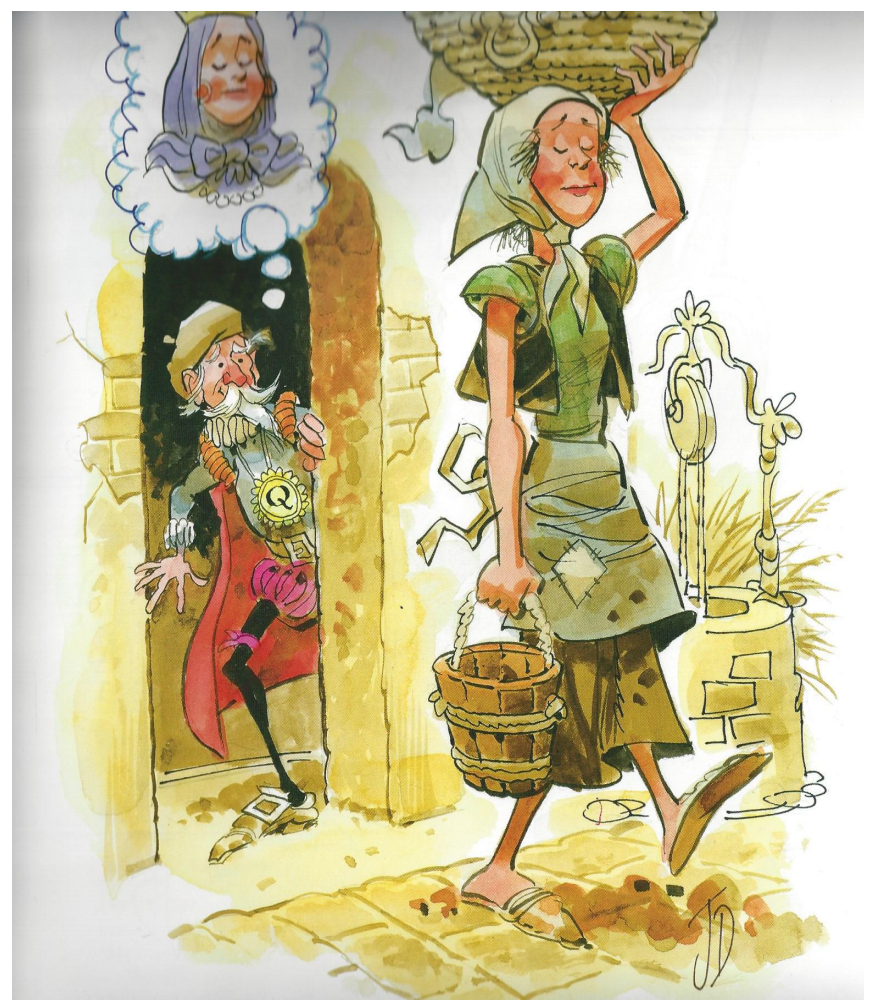

The afore reviewed contradictions of Davis's images demonstrate that the illustrations do not aid in understanding Cervantes's original intent of his text. However, these inaccuracies do not pose lasting impressions on anyone or anything, unlike the representation of Sancho Panza's in Lathrop's book that depicts a negative image of the Mexican population. This depiction of Sancho Panza is not the first time in which the stereotype has taken form in this character. He has been frequently represented as a stereotypic Mexican in several adaptations of Cervantes's Don Quixote. One animated production, A Storybook Classic - Don Quixote (1987), is an example of the perception of Sancho as a typical Mexican in appearance and behavior: a low- 
class farmer that takes advantage of upper-class assistance. He has a mustache, a sombrero, terrible teeth and a distinctly Spanish accent.

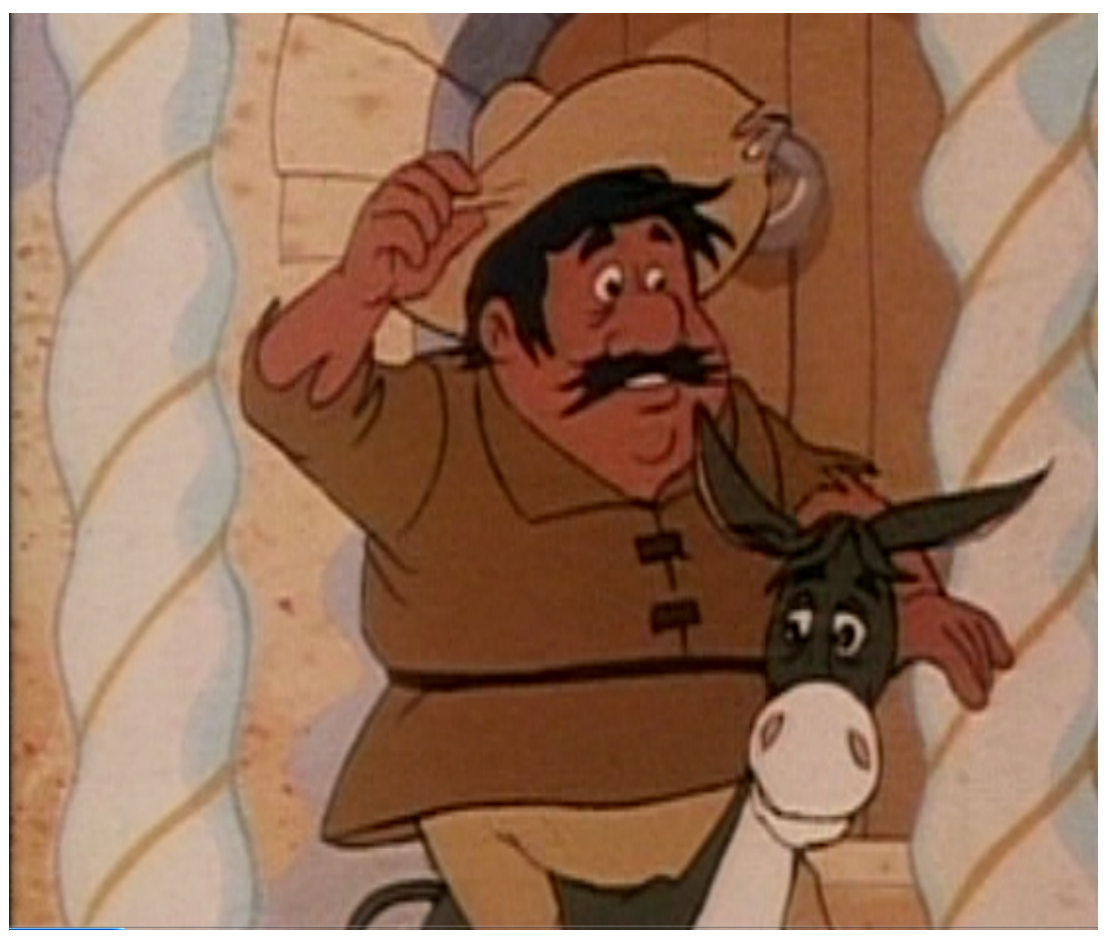

Sancho is also depicted similarly in Lathrop's The Misadventures of Don Quixote. He is shown with the same buckteeth, large hat and otherwise messy appearance. He is explicitly shown as needy when the Duke hands him money for governing the "island." With his hands outward, buckteeth protruding, and belly out, he is the epitome of the stereotypic needy, dependent and dirty Mexican. 
South 30

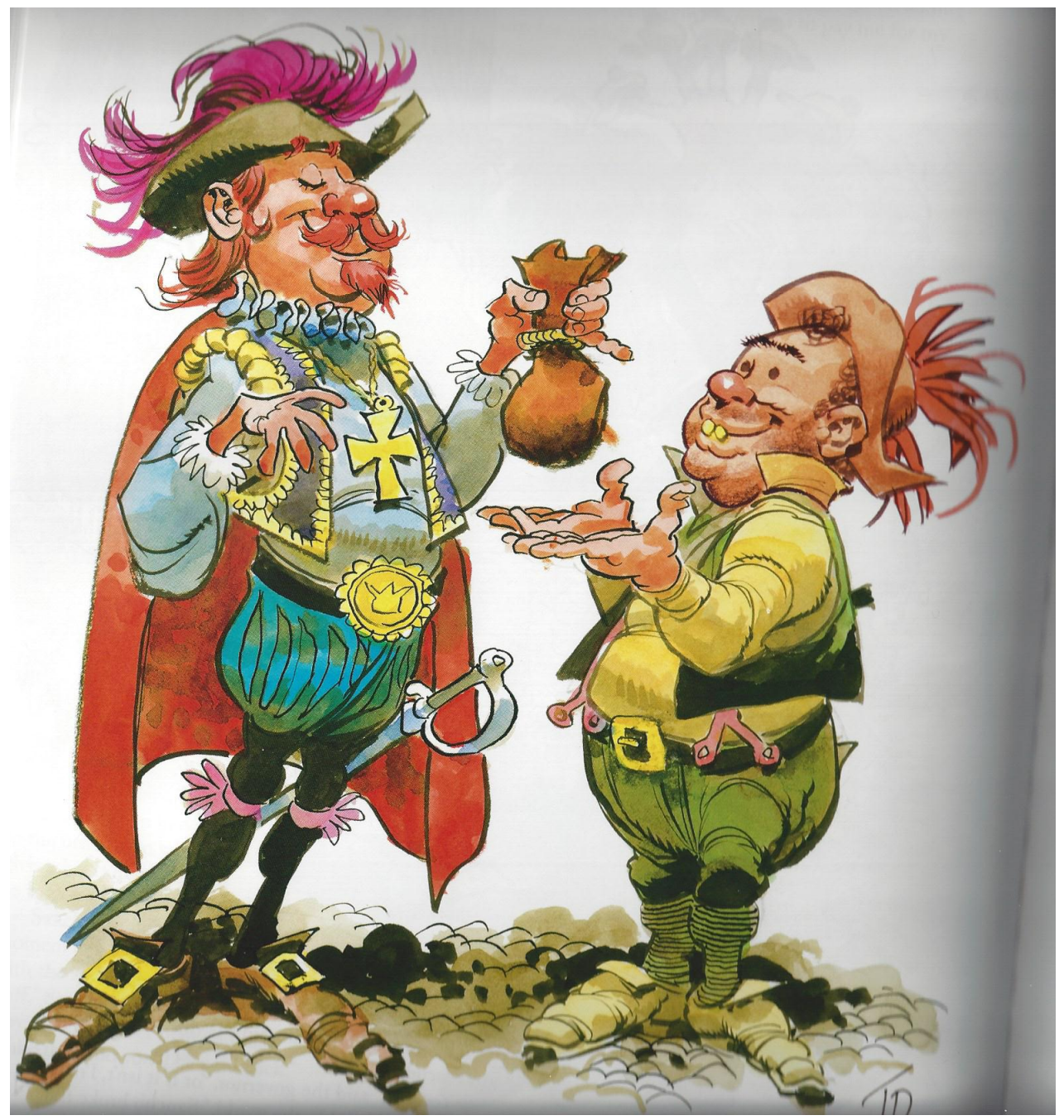

At the end of the story, when Don Quixote and Sancho return home, Sancho holds up his sack of money from the Duke to Don Quixote while Don Quixote smiles at him. The impact of this illustration reiterates the concentration Lathrop's Sancho, symbolic of Mexico, has on fiscal gains. 


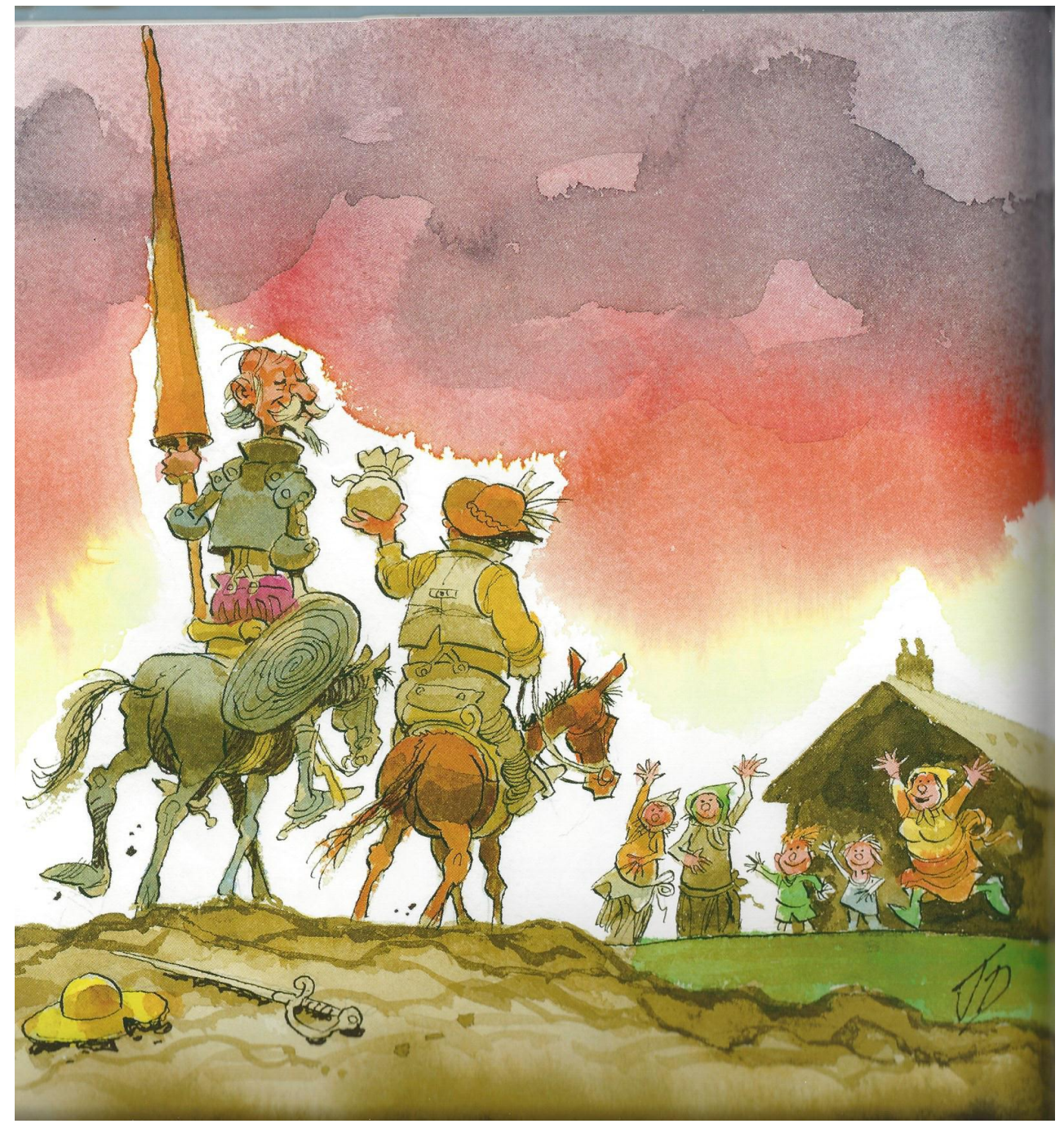

The illustrations in Lathrop's text have a profound effect on the creation and perpetuation of stereotypes of Hispanics, the largest minority group in the United States, made worse by the fact that children ages 6 to 8 are unknowingly absorbing these racist perspectives. To the middleclass American, the peasant Mexican is typically characterized as

A person lacking in cleanliness (he is unshaven, sloppy, a "greaser"), not oriented toward American socially approved goals (he is unworried, unambitious, indolent $), \ldots$ who is uneducated, ... [and] unable to distinguish between proper religious belief and "superstition." (Humphrey) 
Based on Davis's drawings, Sancho no doubt falls into this characterization of a Mexican. He appears filthy; he works on a farm, and he complacently accompanies Don Quixote while disregarding his familial responsibilities. 


\section{Animated Production: UB IWERKS's Don Quixote}

Production company UB IWERKS's cartoon entitled Don Quixote was released in 1934. There is no dialogue; the program is only musically scored. It is 8 minutes, 7 seconds long and it is in color. As a cartoon, it is geared toward a younger audience, most likely children between the ages of 6 and 8 . Based on the film culture of the 1930s, this cartoon would have been watched prior to the starting of a feature movie presentation since at-home televisions were not yet popular at this time ("Radio"). Therefore, a large adult audience would have seen this cartoon. Currently, the cartoon by UB IWERKS is accessible on tvdays.com and youtube.com. This production is 80 years old, but is timeless. The medium of the animation is largely responsible for the ability to still relate to the cartoon. UB IWERKS's cartoon has been watched by the youth of the 1970 s, approximately 40 years after its original production date. According to two of my interviewees, this cartoon is one of the foundations in their understanding of Don Quixote, as noted in my introduction. What they gleaned from this cartoon has not been lost, but instead, has impacted what they now understand about Don Quixote.

The cartoon opens with Don Quixote sitting in a guarded padded cell. The view is then taken inside the cell where a man, presumably Don Quixote, is sitting on the floor reading books about knights. The camera shifts to Don Quixote's view and the pages of the book he is reading come to life. At this moment, Don Quixote stands up and begins reenacting the stories. The guard hears the noise Don Quixote is making and enters the cell. Don Quixote battles the guard, defeats him and escapes. Don Quixote runs to his freedom. As he swings from the window of the building where he is being kept, he falls into a bin that on the side reads, "ye olde junk," that is being pulled by a skinny, grey horse. While Don Quixote and his horse set off on their adventures, the alarms sound that he has escaped from the padded cell; the guard begins to try to 
track him down. Don Quixote first comes across a windmill that he ultimately defeats. Following his victory, he continues his journey when he hears shouting from a far away building with construction equipment out front. Don Quixote imagines this building to be a castle guarded by a ferocious dragon. He overcomes his enemy outside and enters. Once to the top floor of the building, he hears the cries of distress from his damsel and enters the room. The woman inside is actually playing the piano and singing. She turns to Don Quixote and immediately becomes infatuated with him. The guard that had been tracking Don Quixote finally catches up with him, and at this moment, Don Quixote is able to run free from the woman. Both the guard and Don Quixote sprint back to the padded cell; lock themselves inside and burn all of the books that Don Quixote initially read that ignited his knightly desires.

The ability to understand Don Quixote's lunacy is crucial to the understanding of the Cervantine narration. The indication that Don Quixote has gone crazy from reading too many novels about knighthood is demonstrated by showing him in a padded cell, surrounded by towers of books about knights. The placement of Don Quixote in prison is perhaps the quickest and most efficient way to represent his dedication to a chivalrous way of life. The desire to break free from his monotonous days and to bring chivalry into the world is shown by his defeat of the guard of the cell. Don Quixote is no longer satisfied with reading books of knighthood. He must bring the stories to life out in the free world. Prior to even seeing Don Quixote, a coo-coo clock sounds in the background. When the cartoon begins, Don Quixote is reading one novel entitled, When Knights Were Bold, and although the titles of other books are not completely legible, the word "knight," however, can be clearly read on the spine of each book. Therefore, there is a clear connection present between Don Quixote and his over indulgence of an abundance of chivalric literature. Additionally, Don Quixote's projection of knighthood novels on reality is vital to 
understanding how committed he was to his chivalric lunacy. This production does appropriately show the way his imagination became his reality. In the cartoon, while Don Quixote reads the story in his cell, he attentively sits upright and the characters on the page begin to move as though they are real, live human beings. At this point, Don Quixote lifts the hat he is wearing and bats fly out, alluding to the characterization of his actions as "batty," or crazy. When he reaches the point in the book where the dark and white knight are battling, he begins to chew on his nails, then "battles" with the air with a broomstick. Then, he proceeds to gallop on the broom as though it were a horse. It is in this moment that Don Quixote's absolute transformation into knighthood has come off of the page and become part of his existence. In trying to reenact stories of knighthood, Don Quixote's worldly distortion is clearly demonstrated. When Don Quixote does escape from his cell, the images previously seen from his book of knighthood are superimposed over his face. His eyes spin, illustrating his lack of control to behave within the norms of society, and once the images have ended, Don Quixote sets off on his journey. The connection between his obsession with the books and his new "freedom" is thus created. Though he is outside of the prison cell, the images of the books that made him mad still possess him to behave knightly.

Don Quixote's dedication to behave chivalrously compels him to perceive enemies when there are only elements of everyday life. As Don Quixote continues his journey, he comes across an old, grey building with an excavator out front which he perceives to be a castle guarded by a dragon. Don Quixote's vision of a dragon inserts Anglo-Saxon mythology (Classen) into the cartoon and further separates UB IWERKS's version from the original text. Additionally, the insertion of construction equipment, the incorporated color scale, and the image of Don Quixote 
riding a horse juxtapose the two concepts of modernization and antiquity to fit the needs of the time.

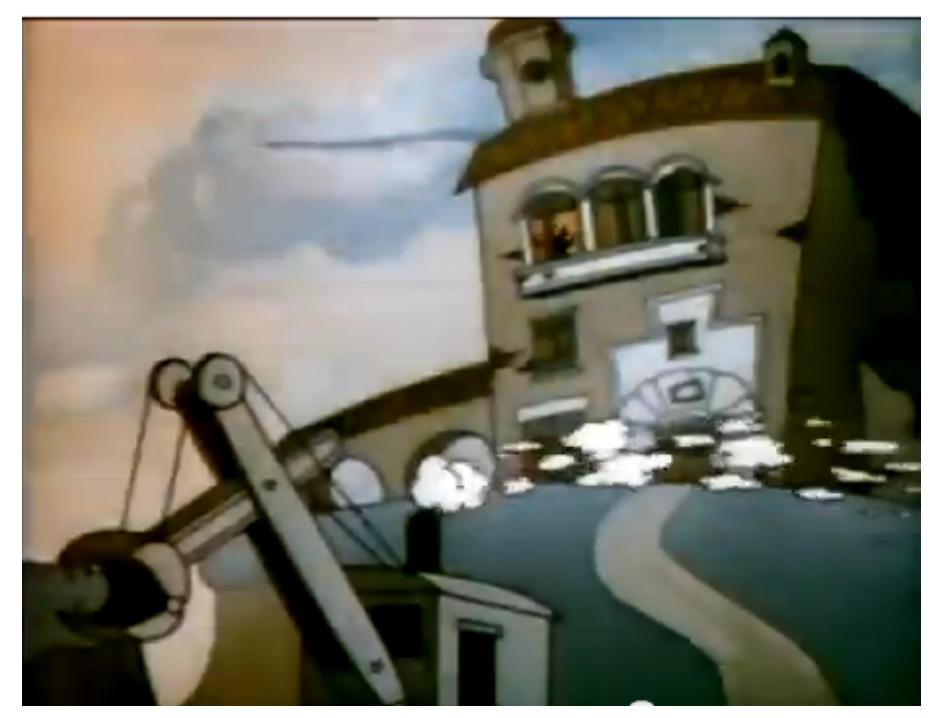

This cartoon was produced in the 1934, following a decade of the United States' manufacturing boom ("Industrial”). By showing a piece of commonly known construction machinery, the audience would have been able to connect with the story despite the fact that it originated in a foreign country. As a symbol of economic power, the audience would have also felt a sense of pride, which would have been needed during the year this cartoon was released. During this time, the United States was five years into their economic downturn, The Great Depression (1929 - c.1940). Businesses were closing and work was hard to find, shown by the grey building symbolizing the lack of vibrancy in the workforce. The only images that are displayed in bright colors are Don Quixote and the damsel, or rather: the innovative thinker and the precious new way of life in the United States. The bad guy that attacks the damsel would therefore represent the history of destruction that threatens the success of the country. Don Quixote, dressed in light colors, enters the room to save the woman being choked by a man dressed in all black. 


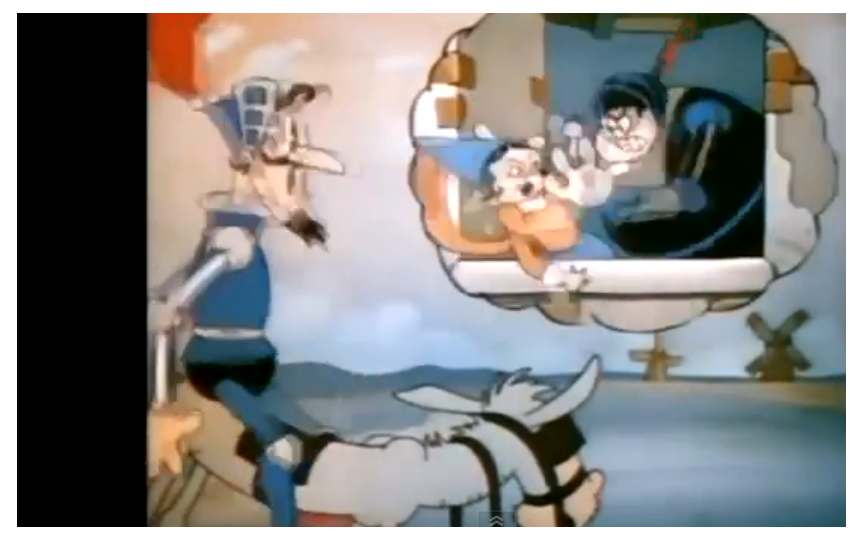

UB IWERK's cartoon “bad guy” is an angry, dark-skinned male with a dark mustache.

During the Great Depression, many immigrant workers both from Spain and Latin American countries were forced or compelled to leave the United States since it was perceived that the immigrants were stealing the jobs away from the deserving Americans. In the cartoon, which is allegoric for the social struggle, the white knight defeats the villain and rescues his woman.

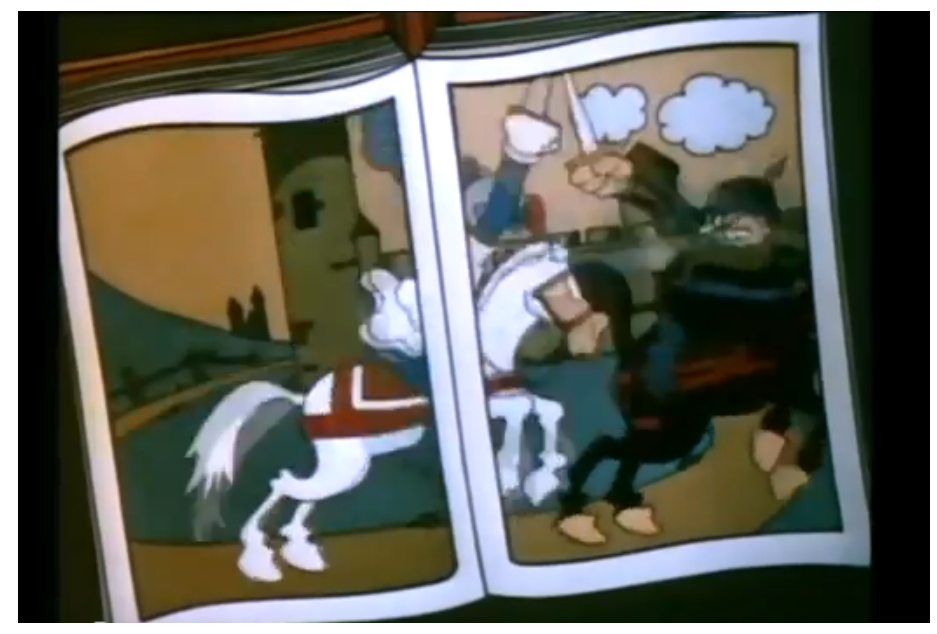

The message that is portrayed by this interaction is of the white man that defeats the Spanish-speaking job stealer and regains dominance and power. Don Quixote imagines the bad guy's demise thereby clearing the way from the past of an unsuccessful market to create a brighter future. 
The economic condition of the 1930s also impacted the way this cartoon was produced. The Great Depression marked a time in which cinematic productions were a much-needed escape from a difficult reality. Therefore, UB IWERKS's version of Don Quixote could not be too depressing. In fact, his humorous and triumphant actions were likely light-hearted and distracting enough for audience members to enjoy a time away from everyday stressors. Don Quixote, although not originally an American literary character, had to represent a kind of victory, hence his triumphs over the windmill and the excavator. At this point, the country had experienced approximately 5 years of an unstable economy, and was finally beginning to return to fiscal stability. Americans were in need of distraction and success stories to which they could relate. UB IWERKS's Don Quixote is an allegory of this achievement: Don Quixote was victimized, experiences tribulations, but eventually emerges victorious, which is what every American wanted at this point for their country. Don Quixote's triumph mirrors the concept of the American Dream. Coined in 1930, the ideals of the expression manifested itself in this portrayal to raise American spirits during a time of relentless struggle. The principles of the “American Dream” dictate, “One could live one's life and pursue one's goals unburdened by older societies' prescribed ideas of class, caste, and social hierarchy" (Kamp). UB IWERK's Don Quixote is shown defeating symbols of past ways of life and ending up happy and successful, just like the United States society and economy was aiming to do.

As society marched toward a brighter future, women's responsibility as an integral part of improving economic success began to morph. The way "Dulcinea" is represented in UB IWERK's animated version demonstrates this new perspective on women's new responsibilities. As Don Quixote rushes into what he perceives as the castle to rescue her, he enters the room to find an unsightly woman playing the piano and singing. Her cries of help were not what Don 
Quixote had hoped for. All he encounters is her horrendous singing. She is an unattractive woman in the same way that Cervantes's Dulcinea is a wretched farm girl. Fundamentally different is that in the cartoon Don Quixote becomes the object of this woman's affection, and she will not let him leave.

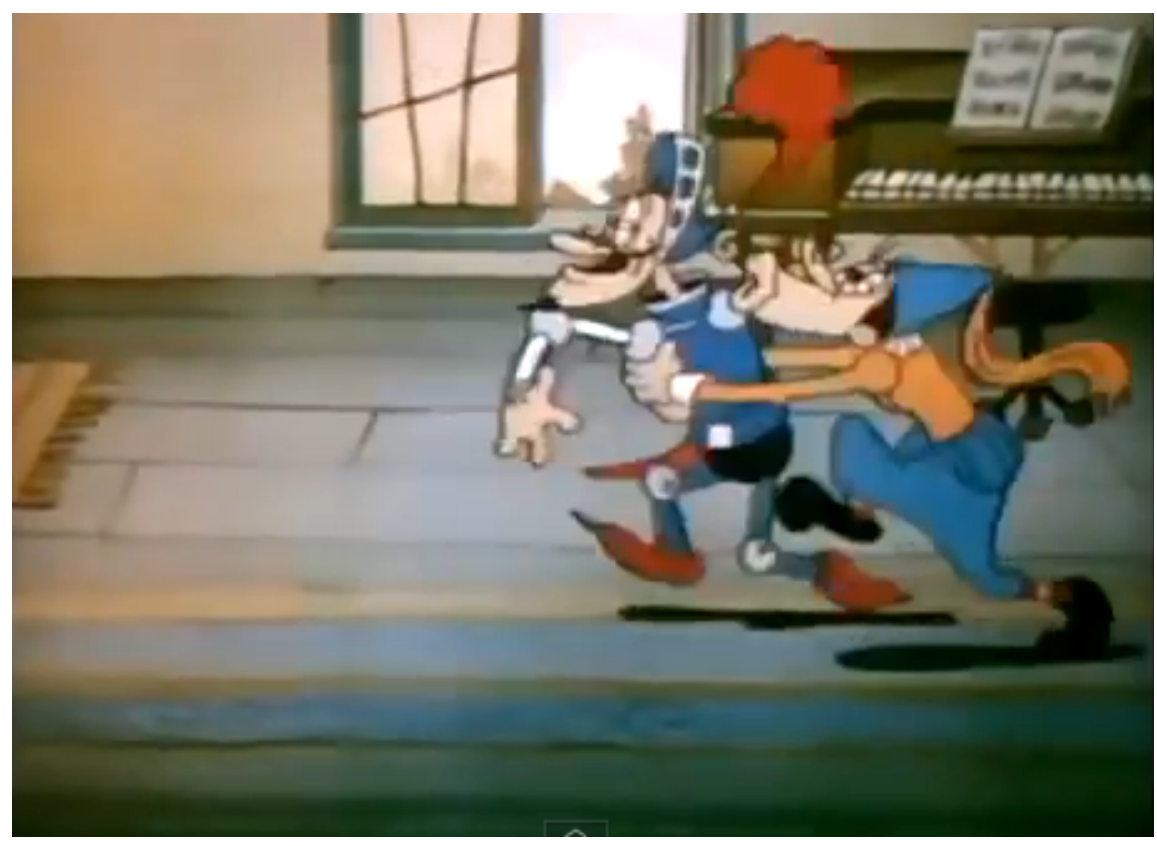

Most white, upper-middle class women in United States during the 1930s were experiencing a shift in responsibilities due to the Great Depression. Stereotypic roles of women were being inverted due to fiscal struggles; women were forced to work in other capacities previously denied to them. That is not to say that these new roles were not met without angst. The perspective that a woman could be professionally successful, but would have issues in romance as a result, was a common portrayal that made its way into this animated version of Cervantes's Don Quixote.

The concept of the "New Woman" from the late-nineteenth century, early twentieth century identifies from where this angst stems. Most men, churches, radical groups such as the Ku Klux Klan, and even some women rejected this shift in female "morality." During this 
gender-role movement, women became increasingly more present in the public arena. Women were not only a domestic presence, but "glamorous performers, female athletes, 'working girls' employed in city factories and rural textile mills, middle-class daughters entering higher education and professions formerly closed to women, and reformers involved in women's clubs, settlement houses, trade unions, and suffrage" ("Clash"). The animosity, however, frequently lead to their portrayal in these new roles, but with negative repercussions: she could be talented, for example, but she could not also be beautiful with domestic bliss. The woman shown in this version of Don Quixote plays piano beautifully, but is physically and psychologically unappealing to the viewer; her face is characteristically unattractive and she immediately latches onto Don Quixote. The perspective is sent to the audience that the value of a woman lies more in her submissiveness and beauty than her intellect and talent, and the women that choose to contradict this expectation are hideous creatures. As the guard and Don Quixote run away from "Dulcinea," they lock themselves into the cell. The fact that they have chosen to entrap themselves to escape the love-crazed woman insinuates that the two would rather be identified as insane, and give up their freedom than spend time with her. For men, women and children watching this cartoon, it is insinuated that intelligent and talented women are she-devils and to be avoided at all cost. When Don Quixote and the guard return to the safety of the cell, they burn the books about the knights, which they blame for their recent misadventures. The act of burning the novels is their way of extinguishing the possibility that these events could reoccur in the future. The United States was also hoping to not repeat the events that caused their struggles by leaving behind the antiquated economic ways of life. 
South 41 


\section{Animated Production: Disney's Don Quixote}

Disney's rendition of Cervantes's Don Quixote from the Mr. Magoo cartoon series totals approximately 45 minutes. The first part of Don Quixote aired in 1964 followed by the second part, which was seen in 1965. The cartoon is in color and includes a narrative voice as well as dialogue between the characters. The level of English used and the cinematic organization of Disney's production most likely gear the cartoon toward children ages 8 to 10 . In this version of the story, Don Quixote and Sancho Panza both depict racial and cultural groups. The cartoon imperialistically attacks Don Quixote through his speech and actions, and labels him an outlandish dreamer based on his idealistic, stereotypic European comportment. Sancho is never specifically identified as Mexican, but his visual and aural casting as sly, lazy, greedy and dirty connects him to the prejudiced image of a Mexican. Disney's Sancho has a large mustache, a bulbous nose, and his hair is covered by a dirty, brown bandana. When Sancho and Don Quixote leave for their adventures, Sancho's feet appear as though they will touch the ground when he has mounted his donkey. His belly even hits the back of his donkey's neck because it is so big. Consequently, Sancho is taken out of his primary and original role as Don Quixote's squire, free of racial stereotypes, and transformed to fit the prejudiced Mexican image.

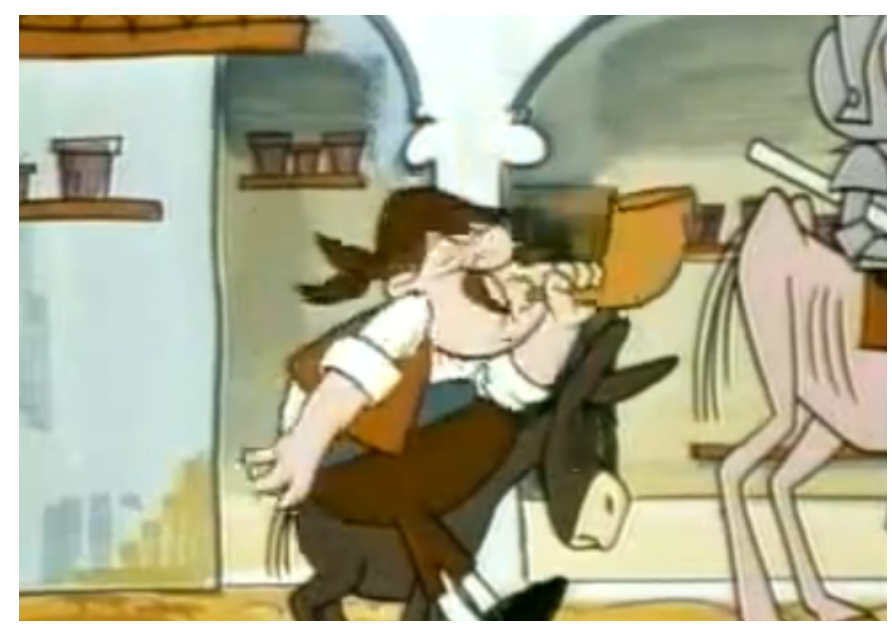


The audience is introduced to Don Quixote in the first thirty seconds of the first episode as a "stumbling, bumbling, romanticist: a dreamer" ("Famous" 0:17-0:20), according to Mr. Magoo, so much unlike himself. However, Mr. Magoo is a foolish character. He walks into the furnace believing that it is his armor to wear for his role as Don Quixote (ibid 0:40). His actions add to the portrayal of Don Quixote as a stupid character, disconnected from reality. Following this remark, Mr. Magoo states that Don Quixote was “silly” (ibid 0:27). The description of Don Quixote as "stumbling, bumbling" and "silly" connotes some level of stupidity. These terms do not imply that Don Quixote is conscious of his knightly behavior, as is suggested in Cervantes's novel, but rather that he is just an insane individual with a ridiculous notion to dub himself a knight. One of the other descriptive terms that Mr. Magoo uses to characterize Don Quixote is "romanticist," a label that comes from the $19^{\text {th }}$ century literary tradition of Romanticism, which emphasizes the power of the imagination and emotion to influence behavior. Don Quixote's actions could be categorized under Romanticism since they are not ruled by reason, but intense desire. The reference to the literary timeframe supports the "silliness" of Don Quixote's actions. Don Quixote has seemingly allowed himself to become enchanted by the novels he reads. He gallivants around Spain in search of knightly adventures and along the way outwardly expresses admiration of his fair love by singing and reciting poetry. Chronologically, however, Cervantes's Don Quixote $(1605,1615)$ could not have been categorized under Romanticism for his novels preceded the movement. The label placed on Don Quixote, a native Spanish figure, suggests a prejudiced cultural perspective that Europeans are idealists, obsessed with beauty, rather than practical capitalists that resign themselves to fiscal responsibilities. Most accounts that distinguish the European lifestyle from the American work ethic concentrate on cultural explanations. The most common perception is that Europeans have a "fuller appreciation of $l a$ 
dolce vita - the sweet life - the Italian version of the idea that life is to be enjoyed, not endured. Work is a means to an end, not an end in itself' (Clements). This notion pervades American thinking, alluding to the fact that like Don Quixote, all Europeans would prefer to spend their time gallivanting around the country than to work hard.

Although Don Quixote exemplifies some of the negative characteristics of the stereotypical European, he nevertheless remains in the controlling position of power because unlike Sancho, he is a white man. The remarks made against the nature of his actions brand him as emotional and irrational, but stop short of marking Don Quixote as an immoral individual. On the contrary, there is a detrimental criticism regarding the depiction of Sancho Panza. His portrayal is frequently one of controversy amongst all visual representations of Cervantes's novel in the United States. Sancho is often depicted as the stereotypic ignorant Mexican that follows the orders of those in charge without thinking independently. In Disney's cartoon, Sancho is visually and aurally presented as a Mexican. The tone and pronunciation of Sancho's speech packs a punch that adds to the negative perception of Mexicans. The first time Disney visually introduces Sancho to the audience, he is outside with his wife and three children. Sancho openly admits he is a fool and will accompany Don Quixote, despite Sancho's lack of financial support for his stereotypically large, Mexican family. His wife bluntly tells Sancho that she would prefer he contracted salaried work, but Sancho goes with Don Quixote despite failing to secure financial compensation. Sancho accepts the position as Don Quixote's squire in hopes that he will be handed an island to rule. Past the first introductory mention of the island in Disney's cartoon, Sancho's potential authority is never again brought up; he is never appointed governor of any island. Since Sancho is never given the island he was promised, the audience is shown 
that he is the subordinate, working-class fool, a representative of the oppressed Mexican minority.

At no point in either Disney episode is the question of finances addressed, although from a practical standpoint, it is a wonder that Sancho can manage to provide for his family. This portrayal of Mexicans as unable to satisfy familial and fiscal responsibilities is relevant to the American perspective that Mexican immigrants drain the government's resources that sustain families, which are unable to support themselves. In the same year the first episode of Disney's cartoon was released, the Bracero program, which allowed Mexican immigrant workers to come to the United States to assist in food production during the Korean War ended (Gutiérrez). This lead to drastic increases in illegal immigration since the need for workers still existed although the agreement with Mexico to legally import laborers had ceased. Mexicans were quickly labeled as "moochers," as people taking advantage of the well-established American economic system. Many Americans quickly developed a fear that Mexicans were marring their country's economic stability and stealing their jobs. By depicting Mexicans as lower class, Americans could believe that they remained superior to their working-class threat. This fear manifested itself among Americans as animosity toward Mexicans and that hostility is expressed in this animated production. The tone of Sancho's voice differs from Don Quixote's, distinguishing them audibly and visually. Where Don Quixote just sounds like an old, American male, Sancho's voice is nasal. He linguistically conforms to the Spanish stereotype, pronouncing his "I"s as Americans would pronounce their "E"s. Without having the knowledge of linguistic differences between English and Spanish, one may assume that his pronunciation is a result of poor education. More noticeably, Sancho speaks with poor enunciation, which adds to the opinion of the ignorant 
Mexican. Not only does he not work for money as all "good Americans" do, but he does not articulate his words.

Although never explicitly stated, Sancho, as the representation of a Mexican, remains subordinate to the white male figure, Don Quixote. While Don Quixote is characterized as insane and engulfed in a "Romantic" reality, Sancho concedes and follows the orders of Don Quixote, leaving the ethnic and racial hierarchy undisturbed. When Don Quixote and Sancho embark on their numerous adventures, Disney recurrently displays Sancho shadowing Don Quixote. Sancho's position behind the European figure, Don Quixote, insinuates the second-class status of Mexicans to the European-heritage Americans in the United States. Don Quixote rides on a tall, white horse and Sancho trudges along on a short, brown donkey. The white horse is a symbol of "speed and power, courage and loyalty, beauty and nobility. Horses, often white ones, have mystical associations with gods and heroes in both Europe and Asia" (Johns). Don Quixote's presence on a white horse makes him a heroic figure while Sancho's donkey suggests that he is a member of the poor, subordinate working class. The same dynamic between dark and light colors present in UB IWERKS's cartoon that demonstrates good versus evil is present in Disney's cartoon, but in this instance depicts noble versus subservient. Don Quixote represents the powerful European culture dominant over the lowly Mexican race embodied by Sancho and his role in the story, a power dynamic that exists in the social context outside of the film. 


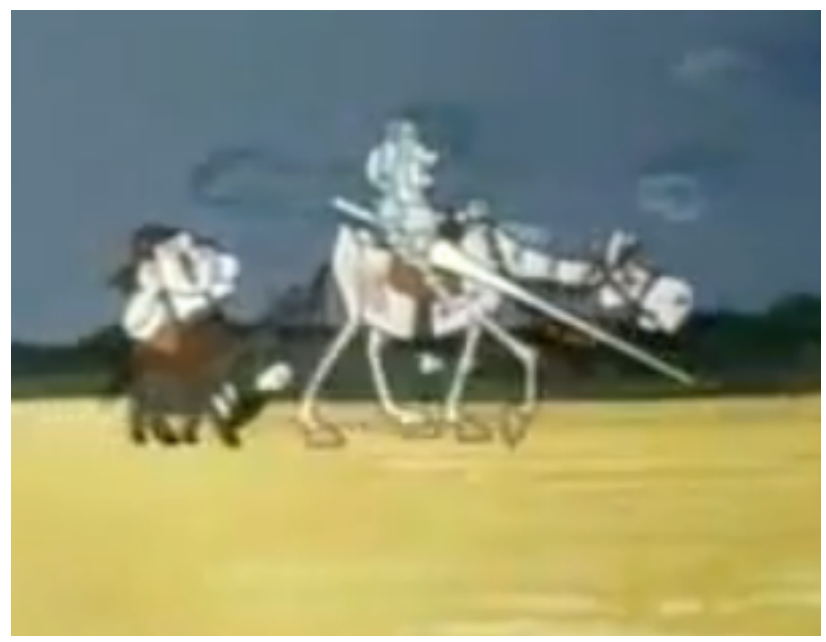

Sancho remains loyal to Don Quixote with hopes of returning home with some type of reward in hand. The comment Sancho makes at the beginning of their second departure on their adventures confirms the fact that he is the "fool" he has labeled himself as. The educated student, Sansón Carrasco, identified in Disney’s version as Sansón “Borrasco," asks why Sancho would accompany Don Quixote if he is really as insane as Sancho claims. Although Don Quixote behaves foolishly because he has become enveloped in the books of knighthood, Sancho has acknowledged his lunacy but accompanies him anyway: "If he is mad, then he is greatly mad, and I am an admirer of greatness" ("Famous" II 2:27-2:35). Granted, Sancho behaved identically in Cervantes's novel. However, since Disney has already established a Mexican image of Sancho, rather than depicting Cervantes's concept of faithfulness between squire and master, Sancho's irrational, stereotypic Mexican behavior is further supported by his self-contradiction and self-endangerment. In the Cervantine novel, Sancho is supposed to be the reasoning force behind Don Quixote's adventures. In Disney's cartoon, Sancho feeds Don Quixote's lunacy. Instead of encouraging a snap back into reality, he supports Don Quixote's ideas, one of which includes the enchantment of Dulcinea. When Don Quixote sends Sancho to call upon Dulcinea, Sancho must be creative because no one, including Don Quixote, has ever laid eyes on her. 
When Sancho spots three women, he returns to tell his master that his fair maiden is heading their way. Don Quixote exclaims that he sees "three fat wenches on mangy old donkeys" ("Famous" II 5:30-5:34). Sancho corrects Don Quixote, informing him that enchanters must have bewitched his eyes for what he in fact sees is a beautiful, elegant Dulcinea and her two ladies in waiting; Don Quixote believes him. Sancho's admitted foolishness is proven since he propagates Don Quixote's quest for knighthood by fostering Don Quixote's lunacy.

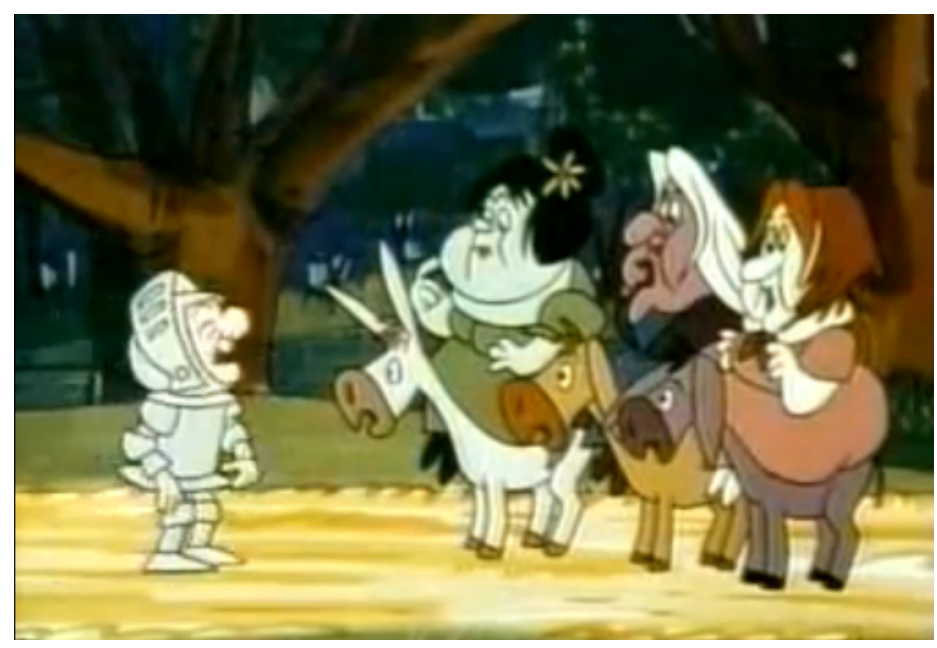

This event in Disney's version of the cartoon, as well as others, matches the original novel. However, the European and Mexican depictions of Don Quixote and Sancho Panza transform the similar occurrences into further supporting remarks about racial prejudices. Cervantes's Don Quixote was not a figure of the European stereotype and Sancho was not intended to represent all Mexicans, but the Americanization of the story makes the characters the embodiment of the imperialistic perspective. 


\section{Conclusion}

Argentina Palacios, Tom Lathrop, UB IWERKS and Disney's variations of Cervantes's Don Quixote have been created to meet the needs of a growing market for international-based works of entertainment because of the increasing multiculturalism in the United States. In response to this infiltration, foreign characters are transformed into American ones portrayed in literature and cartoons. Stereotypes are thus created and/or reinforced, affecting the acceptance of diversity.

Argentina Palacios's Adventures of Don Quixote includes the socially accepted theme of the American Dream. The book has been turned into a suitable children's story because of the diminished fearful impact of the messages from Cervantes's Don Quixote. At first glance, it appears that Palacios has successfully created a version of Don Quixote for youth that includes many of the truths of reality in the original text. Upon further scrutiny, in fact, to sell her book, she has implemented the American Dream to soften the blow of the Cervantes's text and turn the story into a light-hearted, everlasting tale of victory. UB IWERKS's cartoon, "Don Quixote” also incorporates the concept of the American Dream, but for a reason unique to that of Palacios's book. Created to distract its audience from economic depression, this cartoon was intended to give Americans a sense of pride, accomplishment and hope that the country would return to power, despite the current state of disheartenment. During this time, the role of the woman began to morph. This "New Woman" went into the masculine workforce, and frightened members of society with her new freedom and independence. The visual portrayal of the dreaded change is shown in this cartoon in the form of the obsessive woman that falls in love with UB IWERKS's Don Quixote. Ideals of the United States make the cartoon and book more relatable to an 
audience, foreign to the original text. Cervantes's story was easily adaptable in the United States, provided that certain elements were molded to fit the needs of an American audience.

The graphic nature of Tom Lathrop's The Misadventures of Don Quixote visually attacks racial stereotypes, while confusing the young audience for which the book is intended. The written and illustrated narratives at times contradict one another, making the storyline challenging to follow. In addition, there are numerous evident misnomers that incorrectly portray events from Cervantes's novel. Though changes like this can be overlooked, Sancho Panza, Don Quixote's sidekick, is portrayed as a fat, bucktoothed, greedy Mexican. In the $21^{\text {st }}$ century, such depictions of Spanish-speakers are influential on young, impressionable minds since the controversy over the increasing Hispanic population continues to intensify in the United States. Similarly, Disney's “Mr. Magoo’s Don Quixote” characterizes Sancho Panza as a stereotypic Mexican, subordinate to his master, Don Quixote. Even though Mr. Magoo defines Don Quixote as "silly," he is still the hand of power while Sancho is a self-proclaimed fool that embarks on outlandish adventures with Don Quixote. Sancho is visually associated with the Mexican stereotype of behaving slyly, and appearing short, fat, awkward, dirty, and dependent. The recurrent Mexican interpretation of Sancho impacts the audience. Authors and producers have taken the liberty to portray Sancho as the stereotypic Mexican, even though this drawing of his physical appearance is never described in Cervantes's text. Because of the stereotypes that already exist of Spanish-speakers in the United States, Cervantes's description of Sancho may have been unintentionally illustrated to fit the stereotypic American perspective of the Mexican: the foreigner that is always subordinate. As a result, children's racial perspectives of other ethnic groups are affected by the characterization of Disney's and Tom Lathrop's Sancho Panzas, and the racial hierarchy continues. 
Cervantes's Don Quixote was bastardized by these four versions of the novel. The desire of writers and producers to make the audience receptive to a foreign text in order to sell copies and tickets has forced the story to be modified until it has become nearly its own entity, separate from Cervantes's original intent. 


\section{Works Cited}

A Storybook Classic - Don Quixote. Dir. David Cherkasskiy. Prod. Roz Phillips, Tim BrookeHunt. Perf. Robert Helpmann, Chris Haywood, Phillip Hinton, Peter Kay. Gaiam, 1987. Film.

Bender, Steven W. Greasers and Gringos: Latinos, Law, and the American Imagination. New York: New York UP, 2003. Print.

Burke, Carolyn L., and Joby G. Copenhaver. “Animals as People in Literature.” The National Council of Teachers of English. 81.3 (January 2004): 205-213. Print.

Candelaria, Cordelia Chávez. "Stereotypes." The Greenwood Encyclopedia of Latino Literature. Santa Barbara: ABC-CLIO, 2008. Credo Reference. Web. 8 Feb. 2014.

“Clash of Cultures: The New Woman.” Osu.edu. Web. 5 Jan. 2014.

Classen, E. and Harmer, F.E. (eds.): "An Anglo-Saxon Chronicle from British Museum, Cotton MS. Tiberius B iv." Manchester, 1926. Print.

Clement, Douglas. “European Vacation: Why Americans Work More Than Europeans.” The Federal Reserve Bank of Minneapolis. Publications and Papers, 1 Dec. 2003. Web. 10 Mar. 2014.

Dewdney, Anna. “How Books Can Teach Your Child to Care.” The Wall Street Journal SpeakEasy. 7 Aug. 2013. Web. 8 April 2014.

Fuller, Renée. “Understanding Good and Evil in Children's Literature.” Johns Hopkins School of Education. New Horizons for Learning, 1999. Web. 8 April 2014.

Gutiérrez, David G. “An Historic Overview of Latino Immigration and the Demographic Transformation of the United States." Nps.gov. National Park Service, n.d. Web. 10 Feb. 2014. 
Humphrey, Norman Daymond. "Ethnic Images and Stereotypes of Mexicans and Americans." The American Journal of Economics and Sociology 14.3 (Apr. 1955): 306. Print.

“Industrial Revolution.” History.com. A+E Networks, 2009. Web. 5 Jan. 2014.

Jauss, Hans-Robert. Toward an Aesthetic of Reception. Minneapolis: University of Minnesota Press, 1982. 41. Print.

Johns, Catherine. Horses: History, Myth, Art. London: The British Museum Press, 2006. Print. Johnston, Dru. "The Lion King is Hamlet." Blogspot.com. Web. 30 March 2014.

Kamp, David. "Rethinking the American Dream.” Vanity Fair. April 2009. Print.

Lathrop, Tom. The Misadventures of Don Quixote. Newmark: LinguaText, Ltd., 2012. Print.

García Loaeza, Pablo. "Tall Tale, Short Memory: Pecos Bill and the Mexican Other.” The Journal of Popular Culture 47.2 (2014). 226-246. Print.

Mallory, F.R.R. "How to Write a Children's Book on Taboo Subjects." eHow. Web. 28 March 2014.

“Misadventure.” Merriam-Webster's Dictionary and Thesaurus. 2002. Print.

Palacios, Argentina. Adventures of Don Quixote. Garden City: Dover, 1999. Print.

"Radio and Television." History.com. A+E Networks, 2009. Web. 5 Jan. 2014.

Scherkner, Amanda. "9 Life Lessons Everyone Can Learn From These Beloved Classic Children's Books.” The Huffington Post. 3 Feb. 2014. Web. 8 April 2014.

"The Famous Adventures of Mr. Magoo - Mr. Magoos Don Quixote de la Mancha." Youtube.com. Disney, 1964 \& 1965. Web. 10 April 2013.

“Tilting at Windmills.” Wikipedia. Web. 4 Feb. 2014.

Tirrell, Lynne. "Storytelling and Moral Agency." The Journal of Aesthetics and Art Criticism 48.2 (Spring 1990): 115-126. Print. 
“UB IWERKS Don Quixote.”Youtube.com. UB IWERKS, 26 November 1934. Web. 10 April 2013. 